\title{
The Glaucophyta: the blue-green plants in a nutshell
}

\author{
Christopher Jackson', Susan Clayden', Adrian Reyes-Prieto ${ }^{1,2 *}$ \\ ${ }^{1}$ Department of Biology, University of New Brunswick, 10 Bailey Drive, Fredericton, New Brunswick E3B 5A3, Canada \\ ${ }^{2}$ Integrated Microbiology Program, Canadian Institute for Advanced Research, 180 Dundas Street West, Toronto, 0N M5G 1Z8, Canada
}

\begin{abstract}
The Glaucophyta is one of the three major lineages of photosynthetic eukaryotes, together with viridiplants and red algae, united in the presumed monophyletic supergroup Archaeplastida. Glaucophytes constitute a key algal lineage to investigate both the origin of primary plastids and the evolution of algae and plants. Glaucophyte plastids possess exceptional characteristics retained from their cyanobacterial ancestor: phycobilisome antennas, a vestigial peptidoglycan wall, and carboxysome-like bodies. These latter two traits are unique among the Archaeplastida and have been suggested as evidence that the glaucophytes diverged earliest during the diversification of this supergroup. Our knowledge of glaucophytes is limited compared to viridiplants and red algae, and this has restricted our capacity to untangle the early evolution of the Archaeplastida. However, in recent years novel genomic and functional data are increasing our understanding of glaucophyte biology. Diverse comparative studies using information from the nuclear genome of Cyanophora paradoxa and recent transcriptomic data from other glaucophyte species provide support for the common origin of Archaeplastida. Molecular and ultrastructural studies have revealed previously unrecognized diversity in the genera Cyanophora and Glaucocystis. Overall, a series of recent findings are modifying our perspective of glaucophyte diversity and providing fresh approaches to investigate the basic biology of this rare algal group in detail.
\end{abstract}

Keywords: Glaucophyta; Cyanophora; Archaeplastida; primary plastids; cyanelle

\section{Introduction: the putative unique origin of the Archaeplastida}

Glaucophyta Skuja 1954 (or Glaucocystophyta Kies and Kremer 1986) [1,2] is a group of photosynthetic eukaryotes thought to share a common ancestor with red algae (Rhodoplantae; Rhodophyta) and a lineage comprising both green algae and land plants (Viridiplantae; Chloroplastida; Fig. 1). Different taxonomic schemes unite these three groups in the Plantae sensu lato [3] or the Archaeplastida supergroup [4]. Hereafter we use the latter term.

The monophyly of the Archaeplastida is supported by some molecular phylogenetic analyses and comparative studies using nuclear genomic data [5-10]. However, other multi-gene phylogenetic studies have failed to recover the archaeplastidian lineages in a single clade [11-17]. These conflicting phylogenetic signals are possibly caused by intrinsic stochastic and systematic biases in the analyzed nuclear data, unidentified gene paralogies, rampant endosymbiotic gene transfer (EGT) or lineage extinction [10,18-21]. Some nucleocytoplasmic traits that support the monophyly of Archaeplastida are the shared origin of certain enzymes

\footnotetext{
* Corresponding author. Email: areyes@unb.ca
}

Handling Editor: Andrzej Bodył involved in starch biosynthesis [22] and the presence of PRONE (plant-specific Rop nucleotide exchanger) guanine nucleotide exchange factors (proteins that activate GTPases) only in archaeplastidians [23].

While molecular phylogenetics using nuclear data has not provided a conclusive history of the Archaeplastida nucleocytoplasmic ancestor, diverse organelle and nuclear genomic data suggests that the double-membrane-bound plastids present in the three archaeplastidian groups evolved from a single primary endosymbiosis with a cyanobacterium [24-28] (Fig. 1). Evidence supporting the common origin of the Archaeplastida photosynthetic organelles include certain conserved operons in the plastid genomes [29], common enzyme replacements and recruitments in plastid-localized pathways [30,31], shared elements of the plastid protein import machinery of host provenance (e.g., Toc34 and Tic110) [8,32,33], and the common origin of key plastid solute transporters (e.g., ATP/ADP translocator and the UhpC-type hexose transporter) [8,34].

The monophyly of the Archaeplastida and the unique origin of their plastids, (not necessarily coupled evolutionary events - see, for example, alternative views in $[35,36]$ ), are widely accepted scenarios. However, these prominent hypotheses still require conclusive answers to better understand the origin and diversification of the major groups of photosynthetic eukaryotes $[19,26,27]$. A major restriction 
Plantae sensu lato or Archaeplastida

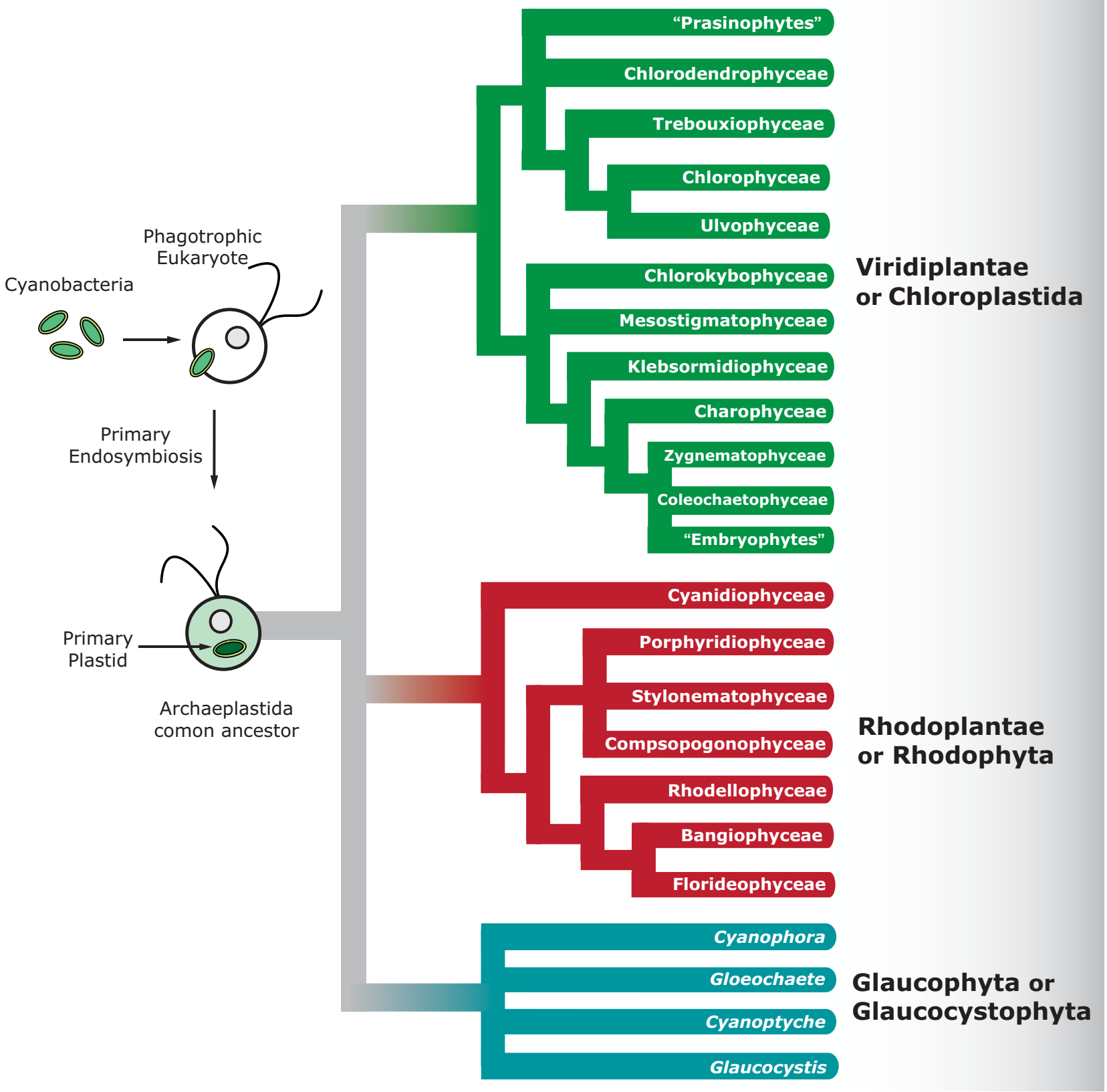

Fig. 1 The Archaeplastida common origin hypothesis. The putative "host" Archaeplastida ancestor was a bi-flagellated phagotrophic eukaryote that captured photosynthetic cyanobacteria as regular prey. The establishment of a stable primary endosymbiotic relationship between the eukaryotic cell and the cyanobacterium involved a series of cellular and molecular events that gave rise to primary plastids and the putative photosynthetic common ancestor of the Viridiplantae, Rhodophyta (red algae) and Glaucophyta [26-28]. The common origin of the Archaeplastida is a widely accepted idea, and supported by diverse types of genomic and functional data, but there are considerable contradictory phylogenetic results that require further investigation. The schematic tree shown in this figure is for illustrative purposes only and does not necessarily represent the true phylogenetic relationships between the different taxa. In the Glaucophyte clade only the names of the four known genera are indicated. The names of viridiplant and red algal taxa presented in the illustrative tree are based on previously published schemes $[138,139]$.

when testing current working hypotheses regarding the evolution of the Archaeplastida has been the relative scarcity of information from Glaucophyta [16,30]. The vast majority of research efforts on glaucophytes have focused on Cyanophora paradoxa, but recent comparative genomic
[8,10,37], molecular phylogenetic [38,39], proteomic [40,41], biochemical [42] and cell biology [43-46] studies have provided novel insights into the biology of this algal group. Our aim here is to provide an overview of the current knowledge of glaucophytes. 


\section{The defining characteristics of Glaucophyta}

Glaucophyta constitute a monophyletic group recovered with strong to full branch support by numerous single[47-49] and multi-locus [5,7,10,50] phylogenetic analyses (although we lack molecular data from some putative genera, see below). Glaucophyte algae are rarely found in large populations and are apparently limited to freshwater environments. The most prominent traits of the lineage are the exceptional characteristics of their plastids, also called cyanelles [51] or muroplasts [52] for historical reasons (Fig. 2). The term Glaucophyta, formed from the Greek roots glaukos (blue-green) and phyton (plant), refers explicitly to the distinctive blue-green color of their photosynthetic organelles. This coloration is caused by the presence of chlorophyll $a$ and the blue phycobiliproteins (i.e., proteins with covalently linked light-capturing molecules called bilins) C-phycocyanin and allophycocyanin [53]. Authors of seminal studies described the glaucophyte plastids as "protoplasm colored bodies", "endosymbiotic blue-green photosynthesizing prokaryotes", "prokaryotic blue-green endocytobionts" or "endocyanomes". Some of these studies even described the blue-green plastids as cyanobacterial species [54] and highlighted their "intermediate" characteristics between free-living cells and organelles $[55,56]$. Further molecular studies demonstrated that the glaucophyte blue-green "bodies" are photosynthetic organelles [57-59].

Glaucophyte plastids have non-stacked thylakoids, as also occur in red algae, but are distinguished from other plastids by the presence of a peptidoglycan wall (PGW) and carboxysome-like bodies (CLBs; Fig. 2) [54,60]. These latter two traits are considered plesiomorphic characters for Archaeplastida that have been uniquely retained in glaucophytes (extended descriptions of these two traits are provided in the section "The blue-green plastids of glaucophytes" below). Given the putative ancestral nature of both the PGW and the CLBs, glaucophytes have been considered as the "earliest diverging" lineage within the $\mathrm{Ar}$ chaeplastida, and colloquially called "living fossils" [61,62]. However, recent comparative genomics and phylogenetic studies have not conclusively resolved the branching position of the group, and the early branching history of the Archaeplastida lineages is still uncertain $[8,10,18,19,63]$. The euglyphid amoeba Paulinella chromatophora Lauterborn 1895 [64], a member of the Rhizaria supergroup, also harbors photosynthetic organelles with PGWs, carboxysomes and concentric thylakoids that visually resemble the glaucophyte plastids [65], but molecular phylogenetic analyses have unambiguously demonstrated the independent origin of the cyanobacterial-derived organelles of glaucophytes and P. chromatophora [66].

Glaucophyte cells are also characterized by the presence of flat vesicles lying underneath the plasma membrane, which resemble the cortical alveolar structures of dinoflagellates, apicomplexans and ciliates (i.e., Alveolates) [24,67]. Nonmotile vegetative cells of colonial glaucophytes have rigid cell walls (composed of cellulose in most species). Motile cells harbor two heterodynamic flagella of unequal length covered with fibrillar (non-tubular) hairs (Tab. 1). The presence of hairs on glaucophyte flagella has been noted as a similarity to cryptophyte flagella [68], but the hairs in the latter group have a tubular ultrastructure different from the fibrillar nature of glaucophyte flagellar hairs [69]. Similar to red algae [70], glaucophytes accumulate reserve
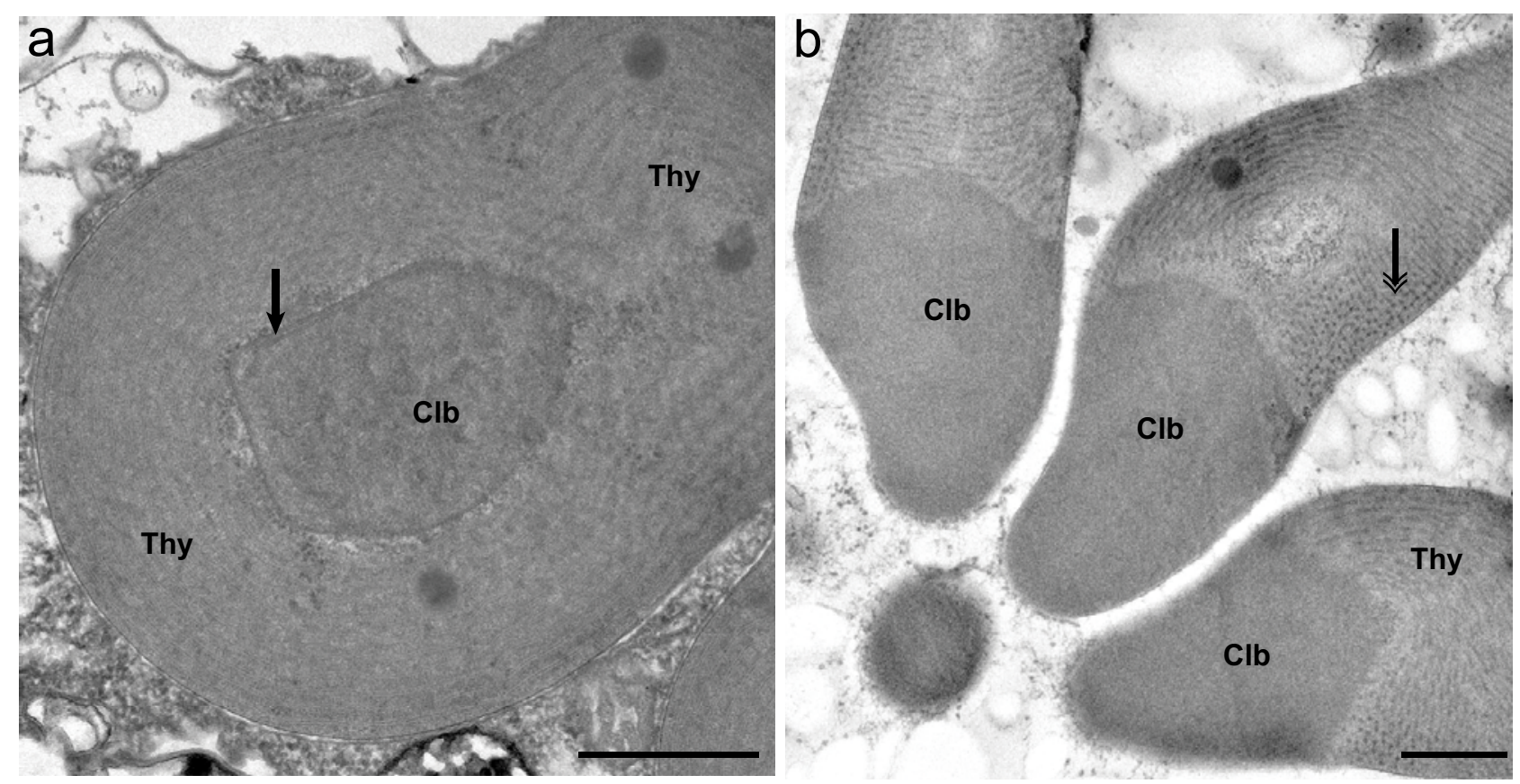

Fig. 2 Unique plastids traits in glaucophyte plastids. Transmission electron microscopy cross-sections of (a) Cyanoptyche gloeocystis (SAG 4.97) and (b) Glaucocystis nostochinearum (SAG 229-2) plastids. The electron-dense carboxysome-like body (Clb) of Cyanoptyche gloeocystis, localized in the center of the organelle, has a shell-like structure (black arrow) and a regular polygonal form (a). In contrast, the Glaucocystis $\mathrm{Clb}$ is localized at one organelle end and shows no presence of a shell-like cover (b). The double-headed arrow highlights the electron-dense phycobilosomes arranged in the non-stacked concentric thylakoidal membranes (Thy). Scale bars represent $0.5 \mu \mathrm{m}$. 
polysaccharides in their cytoplasm [71], whereas viridiplants store polysaccharide granules inside their plastids [72]. Both glaucophytes and viridiplants use starch $[\mathrm{a} \sim 1: 3$ ratio mixture of amylose (unbranched $\alpha$-1,4-linked D-glucose chains) and amylopectin ( $\alpha$-1,4- D-glucose polymer with frequent $\alpha$-1,6-branching points)] as reserve polysaccharide, whereas most red algae store an amylopectin-like compound called floridean starch (a $\alpha$-1,4-linked D-glucose polymer with numerous $\alpha-1,6$ glucosidic branch points) $[70,73,74]$. Glaucophytes undergo open mitosis and longitudinal cytokinesis. Asexual reproduction occurs by generation of zoospores (i.e., motile vegetative spores) or non-motile autospores (Tab. 1). Sexual reproduction has not yet been reported in glaucophytes [2].

\section{Glaucophyte diversity}

In the most recent typification of the glaucophyte group only eight genera have been described [2] and only isolates of Gloeochaete Lagerheim 1883, Glaucocystis Itzigsohn 1868, Cyanophora Korshikov 1924, and Cyanoptyche Pascher 1929 are present in microbial culture collections (Tab. 1; Fig. 3). Other presumed members of the Glaucophyta are Peliaina cyanea Pascher 1929, Strobilomonas cyaneus Schiller 1954, Glaucocystopsis africana Bourrelly 1960 and Chalarodora azurea Pascher 1929 [2], but we lack both cell cultures and molecular data for these taxa. Specimens identified as Chalarodora azurea were recently isolated in Slovakia, but attempts to establish cell cultures were unsuccessful. No molecular data from these specimens were generated [75].

\section{The four genera in culture collections}

The delimitation of the genera Glaucocystis, Cyanoptyche, Gloeochaete, and Cyanophora were confirmed in recent molecular analyses [38,39]. Here we describe characteristics of each genus based on morphological observations of representative species available in current microbial collections.

\section{Glaucocystis}

Cells occur singly or in a group. When in a group (cluster) the cells share a common matrix that is bound by the original mother cell wall (Fig. 3a; Tab. 1). Cell complement in a cluster is variable, for example, $1,2,1+2,2+2,1+2+(2+2)$, ... etc. The cell shape is typically oval; the mother wall is also oval (Fig. 3a), or with lobes, or sloughed. Flagella are reported [56,76,77] with microtubule arrangements 9+0 [77] or 9+9+0 [56], typical cruciate roots [77] yet "rudimentary" [76]. The evidence for flagella in Glaucocystis is unclear and requires verification. Plastids are in star-shaped groups with the component plastids long and droplet-like, tapered proximally (Fig. 2b) and broadened distally.

Tab. 1 Characteristics of cells in glaucophyte genera.

\begin{tabular}{|c|c|c|c|c|}
\hline & Cyanophora & Cyanoptyche & Glaucocystis & Gloeochaete \\
\hline Cell wall & - & + & + & + \\
\hline Mother cell wall & - & - & + & - \\
\hline Zoospores & + & + & $?^{1}$ & + \\
\hline Flagella $^{2,3}$ & + & + & rudimentary ${ }^{4}$ & + \\
\hline Setae & - & - & - & + \\
\hline Plastid number / cell & $1-2$ & to $\sim 90^{3}$ & $\sim 9(+)$ & $>9$ \\
\hline Carboxysome-like body & + & + & + & + \\
\hline
\end{tabular}

${ }^{1}$ Kies and Kremer [2]. ${ }^{2,3}$ Kies [56,78]. ${ }^{4}$ Willison and Brown [76].
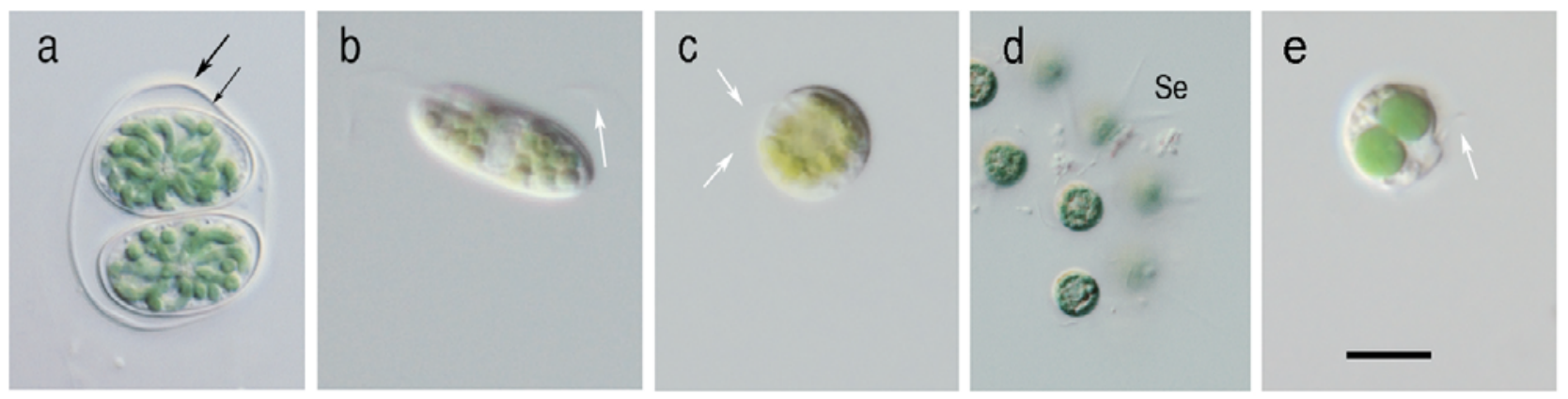

Fig. 3 Glaucophyte cells in light microscopy. a Autospores of Glaucocystis (G. nostochinearum strain BBH, UNB culture collection). Daughter cell with outer wall (thin arrow) surrounded by a mother wall (thick arrow). The individual plastids are in a star-like cluster. b Zoospore of Cyanoptyche (C. gloeocystis SAG 4.97) motile (an arrow points to one of the flagella) at image capture. c A spore rounded up of Cyanoptyche (C. gloeocystis SAG 4.97) with thin cellular extensions (arrows) having the appearance of flagella. d Cluster of cells of Gloeochaete (G. wittrockiana SAG 46.84) bearing setae (Se). e A cell of Cyanophora (C. cuspidata SAG $45.84^{1}$ ) with putative flagella (arrow). Scale: 10, 20, and $6.7 \mu \mathrm{m}$ (a-c, d, and e, respectively); Nomarski differential interference (DIC) optics. ${ }^{1}$ Deposited as C. paradoxa, described as C. cuspidata [39]. 


\section{Cyanoptyche}

Cells are single or palmella (cells are "at rest" within a common matrix) or zoospores (Fig. 3b; Tab. 1). Cell groups are not bound by the mother cell wall. A palmelloid cell produces a single zoospore of similar or even slightly longer dimensions (cells: $24-36 \mu \mathrm{m}$ in length; zoospores: $32-34$ $\mu \mathrm{m}$ in length [78]). A zoospore swims, slows and takes a spherical shape (Fig. 3c). Plastids are rounded to slightly elongate but less elongate than in Glaucocystis and single, instead of star-like, in arrangement (Fig. 3b).

\section{Gloeochaete}

Cells are single or in a group, with two (Fig. 3c; Tab. 1), or less than two, setae (bristles or hairs) per cell. The type [79] is figured with setae in some of the cells (two or four in a group) in a matrix. The margin of the matrix is described and figured with indistinct laminations [79]. Plastids occur multiply and close together in cells.

\section{Cyanophora}

Cells are small (9-16 $\mu \mathrm{m}$ in length $\times 7 \mu \mathrm{m}$ in width [80]; Fig. 3e; Tab. 1). A cell wall is absent [56]. Bi-flagellate cells divide by binary fission and are able to produce round cysts $[2,80]$. One-to-two plastids (Fig. 3e) or a multiple of two are present in each cell [39]. Plastids often have a slight invagination at mid-periphery sometimes interpreted as evidence of organelle division [39]. The appearance of being in, or arrested in division is possibly a stable morphology. Morphological features explored in the recent delimitation of five species of Cyanophora included cell shape, flatness (dorsal/ventral), ventral groove, flagellar origin, plastid division, and ridged fenestrations (see the "Species diversity in glaucophytes" section below) [39]. Flagellar insertion (invariant) and fenestrations (overlapping) were not informative at the species level in Cyanophora but would be interesting characters to compare among genera of glaucophytes.

\section{Species diversity in glaucophytes}

Despite the importance of glaucophytes in understanding the evolution of photosynthetic eukaryotes, morphological and molecular studies of the different genera and species of the group are scarce. Recent phylogenetic analyses of the largest glaucophyte taxonomic sample to date, based on plastid ( $p s b \mathrm{~A}$ and $r b c \mathrm{~L}$ ), mitochondrial ( $c o b$ and $c o x 1$ ) and nuclear (ribosomal RNAs and the internal transcribed spacer region, ITS) markers, have revealed evidence of cryptic species diversity in the genera Cyanophora and Glaucocystis $[38,39]$. Phylogenetic analyses of concatenated markers from diverse genomic compartments ( $p s b \mathrm{~A}, c o b, 5 \mathrm{~S}$ and $18 \mathrm{~S}$ rRNAs) revealed considerable genetic divergence between different strains (NIES-763, SAG 29.80, SAG 45.84) originally recognized as Cyanophora paradoxa (Fig. 4) [38]. Consistent with those findings, another recent study proposed the delimitation of five Cyanophora species. The novel taxonomic scheme maintains the Cyanophora paradoxa name for the "Pringsheim strain" (UTEX LB 555; CCMP 329; SAG 29.80) and proposes the new names Cyanophora cuspidata for the C. paradoxa "Kies strain" (SAG 45.84) and Cyanophora kugrensii for the C. paradoxa strain NIES-763. Additionally, the new scheme proposes the retention of the Cyanophora biloba name for the strain UTEX LB 2766 and the new denomination Cyanophora sudae for the strain NIES-764 (Fig. 4) [39].

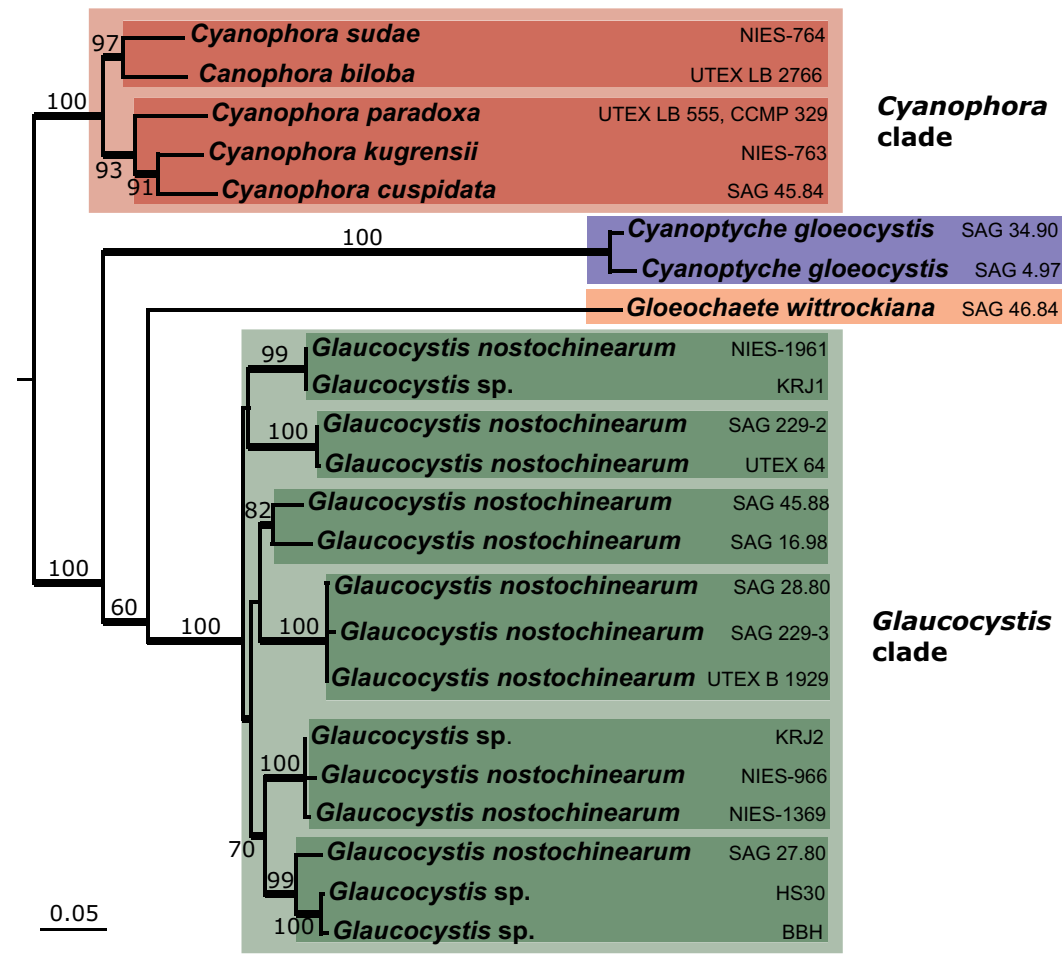

Fig. 4 Cryptic species diversity in Cyanophora and Glaucocystis. Maximum likelihood (ML) phylogenetic tree estimated from a concatenated data set of $p s b \mathrm{~A}$ (plastid gene), $c o b$ (mitochondrial gene) and the nuclear $5.8 \mathrm{~S}$ and $18 \mathrm{~S}$ rRNAs sequences. Numbers near nodes indicate bootstrap proportion support values $>50 \%$ and thick branches indicate Bayesian posterior probabilities $\geq 0.95$. Tree branch lengths are proportional to the number of substitutions per site indicated by the scale bar (see Chong et al. [38] for detailed methods). 


\section{Insights into Archaeplastida and Glaucophyta evolution from comparative genomics}

\section{Phylogenomics of Cyanophora paradoxa}

During the last decade numerous green-algal nuclear genomes have been completely sequenced, with others in process (see Genomes OnLine Database; https:/gold.jgi-psf. org/index) [81], and genomic information from several red algae has been recently published [82-85]. However, only the Cyanophora paradoxa nuclear genome (ca. $70 \mathrm{Mbp}$ ) has been sequenced thus far from glaucophytes [8,63]. A central aim of sequencing the Cyanophora nuclear genome was to investigate the early evolution of photosynthetic eukaryotes and the presumed common origin of Archaeplastida.

Of more than 27000 predicted proteins in the Cyanophora nuclear genome, only 4628 had identifiable homologs from either prokaryotes or other eukaryotes. Phylogenetic analyses of 4445 of these sequences reveal that more than $60 \%$ of the Cyanophora proteins branch ( $\geq 90 \%$ bootstrap support) as sister to red algal and/or viridiplant homologs. Some of these clades containing representatives of the Archaeplastida also include sequences from eukaryotes with secondary plastids of red or green algal origin (e.g., diatoms, haptophytes, euglenophytes). This likely reflects cases of EGT from the secondary endosymbionts [8]. Overall, the large proportion of single-protein phylogenetic trees that recover Archaeplastida monophyly has been interpreted as evidence of the common origin of this supergroup [8]. However, the fact that several multi-locus phylogenetic studies have failed to definitively recover the Archaeplastida monophyly has directed us to the use of complementary analyses of genomic data to identify unique shared signatures. For example, exploring the presence of common gene families or pathways exclusively shared between the three Archaeplastida lineages may provide data to evaluate and compare competing hypotheses, such as the common ancestry scenario versus the possibility of different origins.

Prior to genome-scale sequencing efforts for glaucophytes, the similar subunit composition and the common origin of key components of the plastid protein import apparatus, constituted by the translocons of the outer (TOC) and inner (TIC) membranes, were suggested as evidence of the single origin of the Archaeplastida photosynthetic organelles [32]. The main components of the TOC-TIC apparatus (Toc75, Tic110 and Toc34) [86,87] encoded in the Cyanophora nuclear genome are homologous to red algal and viridiplant counterparts [8], supporting the idea that the "assembly" of the plastid protein import machinery occurred in the common ancestor of the Archaeplastida. Overall, the TOC-TIC complexes of the three archaeplastidian lineages comprise both protein components evolved from the plastid cyanobacterial ancestor (e.g., Toc75 and Tic20) and, importantly, proteins recruited from the host collection (Tic110 and Toc34) [8]. This shared phylogenetic mosaicism (i.e., common recruitments of non-cyanobacterial proteins) of the Archaeplastida TOC-TIC components favors the unique origin of primary plastids over the possibility of multiple independent origins (but see [88-90]). Shared phylogenetic mosaicism is also seen in other key plastidlocalized biochemical pathways in glaucophytes, red algae and viridiplants. For example, certain plastid-targeted enzymes participating in the Calvin-Benson cycle [30] and the biosynthesis of histidine and aromatic amino acids [31] have the same non-cyanobacterial origin in all three Archaeplastida groups. These putative common enzyme recruitments (or replacements) suggest that the common ancestor of the Archaeplastida enlisted proteins for plastid functions before the diversification of the three descendant lineages. Detailed phylogenetic surveys suggest that several of these proteins are products of genes acquired by the eukaryote host from diverse bacterial sources via HGT $[30,31,91,92]$.

A controversial bacterial signature identified in Archaeplastida genomes, recently corroborated by the inclusion of the Cyanophora genome data, is the dozens (between 50 and 70) of genes putatively acquired from Chlamydiaelike bacteria via gene transfer early in the evolution of this eukaryote supergroup [8,22,93-95]. Interestingly, some of these Chlamydiae-derived proteins are plastid-localized, or contain predicted plastid-targeting signals $[93,94]$. The list of putative plastid Chlamydiae-derived proteins includes key proteins shared by glaucophytes, red algae and viridiplants. They include the ATP/ADP translocator (NTT), which regulates the critical exchange of organellar ADP for ATP from cytoplasmic pools, and UhpC-type hexose-phosphate transporters $[8,34]$. Other prominent cases of proteins of Chlamydiae origin encoded in the Archaeplastida genomes are the cytosolic glycogen debranching enzyme (isoamylase; $\mathrm{GlgX}$ ) and the ADP-glucose dependent starch synthase $(\mathrm{Glg} A)[8,22]$. Some authors have proposed that the latter two enzymes, now essential components of the Archaeplastida starch biosynthesis pathway, played key roles in the successful establishment of the eukaryote-cyanobacterium endosymbiosis that led to the origin of the Archaeplastida ancestor. Briefly, this hypothesis postulates that the metabolic interaction of three symbiotic partners (i.e., eukaryote, Chlamydiae-like, and cyanobacterium) established a steady flux of carbon compounds, which resulted in a key event to consolidate a stable eukaryote-cyanobacterium endosymbiosis [22,96]. A recent review published in Acta Societatis Botanicorum Poloniae thoroughly discusses diverse aspects of this tripartite hypothesis [95].

Importantly, some authors consider that the evolutionary scenario offered by the tripartite symbiosis hypothesis is not a compelling explanation for the Chlamydiae-derived genes present in the Archaeplastida genomes. An alternative scenario notes that the number of Chlamydiae-like genes is relatively small and lower than the number of Archaeplastida genes that are likely derived from other bacterial groups (e.g., a few hundreds from diverse proteobacteria and actinobacteria), and that typical HGT from free-living bacteria better explains the presence of Chlamydiae-like sequences [97]. Regardless of the likelihood of the proposed tripartite scenario, the significant physiological roles of some of the Chlamydiae-derived proteins in plastid functions (e.g., NTT and UhpC-type transporter) and polysaccharide metabolism (e.g., GlgA), shared by glaucophytes, red algae and viridiplants, suggests that the recruitment of these proteins from Chlamydiae occurred in the common ancestor of the Archaeplastida [93-95]. 
Subsequent studies of the Cyanophora genomic repertoire have revealed certain glaucophyte genes with homologous sequences present in other major eukaryote groups (e.g., opisthokonts, amoebozoans, rhizarians, excavates, stramenopiles), but absent from viridiplant and red algal genomes. Some examples are the genes encoding the mitochondrialtargeted porin Mdm10, which is part of the endoplasmic reticulum-mitochondria encounter structure (ERMES) [98], and proteins involved in the calcium signaling machinery $\left(\mathrm{Ca}^{2+} \mathrm{SM}\right)$, such as CatSper-like (cation channels of sperm), $\mathrm{CaV}$ (membrane voltage-gated $\mathrm{Ca}^{2+}$ ) and TRP (transient receptor potential) channels [99]. The presence of the ERMES and the $\mathrm{Ca}^{2+} \mathrm{SM}$ in diverse major eukaryotic groups, now including glaucophytes, suggest an ancient origin of these pathways. Likewise, a recent analysis of the archaeplastidian collection of Rab GTPases, which are key regulators of the intracellular membrane traffic, indicates that the GTPase Rab14 is encoded in glaucophyte genomes but not present in the red algal and virdiplant repertoires [100]. The widespread presence of Rab14 in other major eukaryote groups suggests that this protein was part of the Rab GTPase collection of the Archeaplastida common ancestor [100]. Further comparative investigations comprising other glaucophyte complete genomes will be important to understand if those glaucophyte genes associated with ERMES, $\mathrm{Ca}^{2+} \mathrm{SM}$ and part of the Rab GTPase family were lost in red algae and viridiplants.

\section{The endosymbiotic gene collection}

A recurrent question in plant evolutionary genomics is the count of genes that were transferred from the cyanobacterial plastid ancestor into the nuclear genome of the host (i.e., endosymbiotic gene transfer, EGT) [97,101-104]. Analyses of complete Archaeplastida nuclear genomes have provided varying estimates of the number of cyanobacterialderived genes, ranging from 600 to 1700 sequences in different species of land plants (e.g., Oryza sativa, 637 cyanobacterial-derived genes out of 26712 total sequences; Arabidopsis thaliana, between 801 and 1700 out of 30897 and Physcomitrella patens, 903 out of 35 468) [97,101,105], 400 to 900 in unicellular green algae (e.g., Chlamydomonas reinhardtii, between 478 and 897 out of 14200 genes; Ostreococcus tauri, 403 out of 7715) $[97,103]$ and 300 to 700 in the extremophile red alga Cyanidioschyzon merolae ( $\sim 700$ total genes) $[97,105]$. The phylogenomic survey of the Cyanophora genome suggests that only 274 of the 4628 proteins with identified homologs have a putative cyanobacterial origin [8]. If we exclusively consider phylogenomic results from unicellular Archaeplastida, it seems that the ancestral cyanobacterial EGT imprint was in the order of several hundreds of transferred genes (300-900), and that later independent evolutionary events, such as complete genome duplications (which occur relatively frequently in land plants) or adaptive genome reductions (e.g., pico-prasinophytes and hyperthermophilic Cyanidiales), expanded or reduced the total number of cyanobacterial-derived genes in each lineage. Protein targeting predictions for Cyanophora nuclear gene products indicate that the cyanobacterial contribution to the ancestral Archaeplastida genome mostly comprised genes encoding proteins important for the function and housekeeping of the photosynthetic organelle [8,102], and that subsequently some cyanobacterium-derived proteins acquired novel non-plastidic roles [101].

\section{The diversity and origin of phytochromes in glaucophytes}

Phytochromes are widely distributed multi-domain proteins with covalently linked bilin chromophores (i.e., linear tetrapyrroles such as biliverdin, phycoerythrobilin or phycocyanobilin). They act as photoreceptors and play key roles in signal mechanisms regulating numerous physiological responses, such as the gene networks involved in photosynthetic activity and circadian rhythms. Phytochromes have been studied largely in land plants and diverse bacteria, but recent comparative and experimental studies have revealed the presence of phytochromes in diverse photosynthetic eukaryotes, including cryptophytes, diatoms, brown algae, prasinophytes, and now, glaucophytes, thus considerably expanding the catalog of these photosensory proteins in the eukaryote lineage $[45,46]$.

Typical land plant phytochromes sense light in the red/ far-red region (615-740 nm), but some of the phytochromes recently identified in diverse algae are able to capture energy from other wavelengths in addition to the red/far-red window [46]. For example, phytochromes from certain prasinophyte algae absorb orange and yellow light (590-615 nm), whereas phytochromes of the brown alga Ectocarpus siliculosus absorb in the green spectrum region $(510-570 \mathrm{~nm})$ and those from glaucophyte sense blue light (410-480 nm). Together, these diverse phytochromes encompass most of the visual spectrum, raising questions about the physiological roles of the different phytochromes in the diverse algal groups $[45,46]$. Surveys of the Cyanophora paradoxa genome and Gloeochaete wittrockiana transcriptomic data have identified several phytochrome genes in each of these glaucophyte species. Studies of the light absorption properties of some phytochromes from Cyanophora (CparGPS1) and Gloeochaete (GwitGPS1) have revealed photosensory characteristics not yet observed in other eukaryote phytochromes, such as the capacity to sense blue light, as also seen in some cyanobacterial phytochromes. There are certain differences between the photocycles (i.e., the different conformational states of the chromophore molecule depending on the wavelength of the absorbed light) of the analyzed Cyanophora and Gloeochaete phytochromes, which show blue/far-red and red/blue photocycles, respectively, indicating considerable diversity in the photosensory properties of the glaucophyte phytochromes [46]. The physiological role and relevance of the peculiar glaucophyte phytochromes is still to be thoroughly investigated.

Phylogenetic analysis of the phytochrome multi-domain region "PAS-GAF-PHY" from diverse bacterial and eukaryote lineages shows that the glaucophyte and viridiplant phytochromes have a common origin, separate from stramenopile and fungal homologs and independent of cyanobacteria [45]. In contrast to this common origin, the phylogeny of the phytochrome histidine kinase-related output module (HKM) region is not well resolved but suggests a different origin of the glaucophyte and viridiplant sequences, indicating possible replacements of phytochrome domains during the evolution of Archaeplastida. No red algal phytochromes have been reported yet [45]. 


\section{The blue-green plastids of glaucophytes}

\section{The plastid genome of (yanophora paradoxa}

The plastid genome (ptDNA) of Cyanophora paradoxa (strain UTEX LB 555) is the only complete glaucophyte ptDNA deposited in public repositories thus far [59] (Tab. 2), but near-complete ptDNA data from Glaucocystis nostochinearum is reported $[8,106]$. Comparisons of the C. paradoxa and G. nostochinearum ptDNAs show that both the gene content and genome organization are very similar [106]. If multiple gene copies in the inverted repeats are not considered, the total number of protein-coding genes in the C. paradoxa ptDNA is 146 (Tab. 2). This number of genes is higher than the vast majority of viridiplant ptDNAs, but lower than most known red algal ptDNAs (e.g., 233 in the florideophyceaen Grateloupia taiwanensis, and 213 and 224 in the bangiophycean Pyropia yezoensis and Porphyridium purpureum, respectively) [107-109]. Multi-locus phylogenetic analyses of plastid genes suggest the single origin of primary plastids and, indirectly, the common ancestry of the Archaeplastida [5,9]. However, this last inference has to be taken with caution as the absence of data from plastidlacking eukaryote lineages limits potential conclusions from plastid phylogenomics.

\section{The phycobilisomes of Cyanophora}

Phycobilisomes are light-harvesting antenna complexes attached to the stromal face of the thylakoid membranes of cyanobacteria and the plastids of red algae and glaucophytes [110,111] (Fig. 5). Antenna complexes play a central role in photosynthesis by capturing light energy and transferring it to the reaction centers of photosystems I and II. The putative unique origin of primary plastids from a cyanobacterium suggests that phycobilisomes were present in the photosynthetic organelles of the common ancestor of the Archaeplastida, and were later independently lost in the viridiplant branch [112]. Phycobilisomes are proteinaceous complexes composed of a series of rods (6 to 8) connected to a central core [40]. The core and rods are made up of phycobiliprotein molecules aggregated in trimeric or hexameric disks, which are organized in cylindrical macrostructures connected and stabilized by unpigmented linker proteins [113] (Fig. 5).

Tab. 2 Characteristics of Cyanophora paradoxa plastid genome [59].

$\begin{array}{lc}\text { Size }(\mathrm{kb}) & 135.6 \\ \text { Shape (map) } & \text { circular } \\ \text { Protein coding genes }^{1} & 146 \\ \quad \text { Unidentified ORFs } & 11 \\ \quad \text { Hypothetical proteins }^{2} \text { rRNA }^{1} & 13 \\ \text { 16S rRNA }^{1} & 1 \\ \text { 5S rRNA } & 1 \\ \text { Transfer RNAs }^{1} & 1 \\ \text { A + T content }(\%) & 1 \\ \text { Type-I intron } & 36 \\ \end{array}$

${ }^{1}$ Excluding extra copies.
Genomic data from Cyanophora paradoxa reveals that the unpigmented components of the phycobilisomes, comprising the rod-core (CpcG1 and CpcG2), rod-linker (CpcK1, CpcK2 and $\mathrm{CpcD})$ and core-linker $(\mathrm{ApcC} 1, \mathrm{ApcC} 2)$ proteins, are encoded in the nucleus of this alga, whereas the complete set of phycobiliprotein subunits (ApcA, ApcB, ApcD, ApcE, $\mathrm{ApcF}, \mathrm{CpcA}$ and $\mathrm{CpcB}$ ) are encoded in the plastid genome [40,62]. Glaucophyte phycobilisomes show certain compositional and structural differences compared to those of red algae. The most conspicuous difference is the absence of phycoerythrin in the glaucophyte phycobilosomes, which is the most abundant phycobiliprotein in red algal plastids [62]. Structural studies of the Cyanophora paradoxa phycobilisomes suggest that the protein components are arranged in two unusual sub-complexes (organized as ApcE/CpcK1/ $\mathrm{CpcG} 2 / \mathrm{ApcA} / \mathrm{ApcB} / \mathrm{CpcD}$ and $\mathrm{ApcE} / \mathrm{CpcK} 2 / \mathrm{CpcG1/ApcA/}$ $\mathrm{ApcB}$ ), which connect the core and rod sections and serve as a structural framework for the phycobilisome assembly (Fig. 5) [40].

Interestingly, the typical rod-linker protein $\mathrm{CpcC}$, involved in the formation of phycocyanin rods of cyanobacterial and red algal phycobilisomes, has not been found in different Cyanophora paradoxa strains (CCMP329 and NIES 547) [40]. This suggests that the novel Cyanophora proteins CpcK1 and CpcK2, which harbor phycocyanin linker domains, play the role of linking the phycocyanin disks during elongation of the phycobilisome rod (Fig. 5). Phylogenetic analyses of the rod-core (CpcG1 and CpcG2) and the rodlinker (CpcK1 and $\mathrm{CpcK} 2$ ) proteins of Cyanophora indicate that these proteins are products of gene duplications, which probably occurred only in glaucophytes [40]. Further structural and functional studies in other glaucophyte genera will be important to better understand the apparent unique characteristics of the Cyanophora phycobilisomes and their role in the light-harvesting function.

\section{The light harvesting proteins of glaucophytes}

Following the origin of primary plastids, the history of the photosynthetic apparatus in Archaeplastida has involved the intricate evolution of different proteins carrying bound chromophores (i.e., molecules able to absorb certain wavelengths of visible light and to transmit others) to perform light-harvesting roles [114,115]. Based on the presence of chlorophyll-binding motifs in transmembrane regions, most of these chromophore-binding proteins are grouped in the extended light-harvesting complex protein superfamily, which comprises, among other groups, the light-harvesting complex (LHC), the photosystem II subunit S (PSBS) and the LHC-like protein families [114-116].

The Cyanophora nuclear genome exclusively contains genes encoding proteins of the LHC-like family. These include a plastid genome-encoded protein and related nuclear genome-encoded proteins (OHP1 and OHP2) of the high light-inducible (HLIP) subfamily [59] and sequences with domain similarity to proteins belonging to the two-helix stress-enhanced (SEP) subfamily $[8,114]$. Interestingly, the typical red algal and viridiplant three-helix LHC proteins are apparently absent in Cyanophora and Glaucocystis, but the three Archaeplastida groups share the presence of twohelix SEP-like proteins. These latter data add some support 

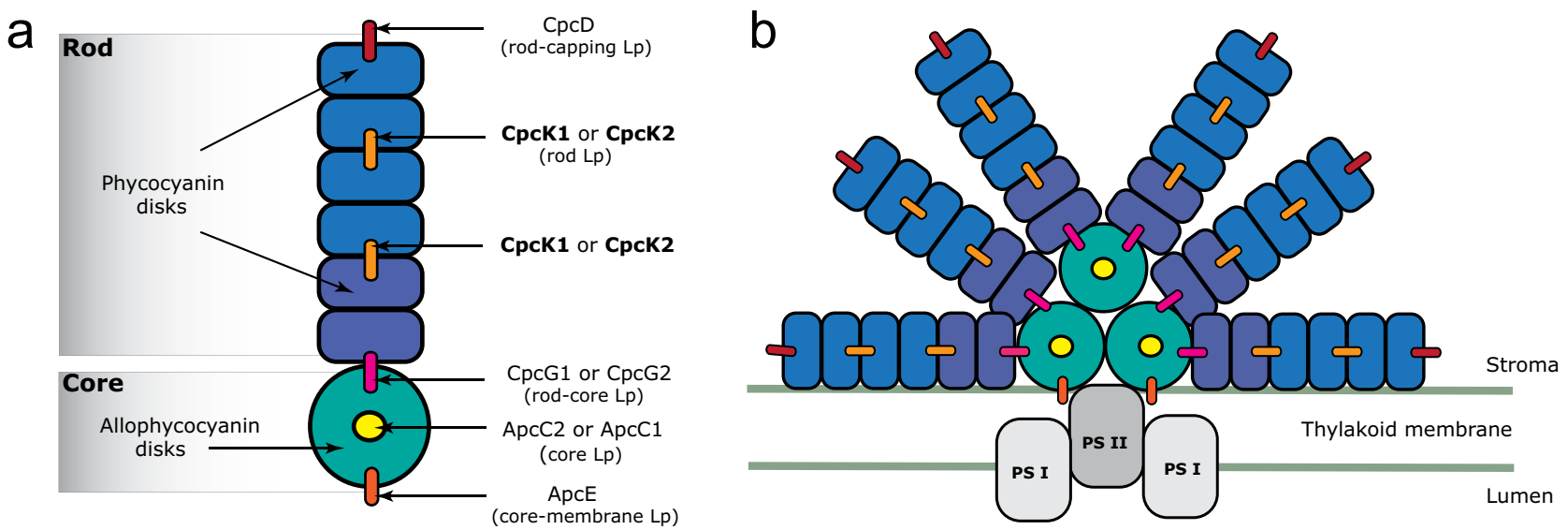

Fig. 5 Schematic model of the Cyanophora paradoxa phycobilisome antenna complex. A single rod and core section (a) illustrates the suggested arrangement of the phycobilisome cylinders (shapes in blue and turquoise) and the skeleton formed by the different linker proteins (Lp) of Cyanophora. The proteins $\mathrm{CpcK} 1$ or $\mathrm{CpcK} 2$ are novel rod linker proteins probably participating in the connection of phycocyanin disks, substituting for the typical cyanobacterial-like rod-linker protein $\mathrm{CpcC}$, which is apparently absent in Cyanophora. The fan-like structure of the phycobilisome complex attached to the stromal side of the thylakoidal membrane (b) shows the core composed of three allophycocyanin cylinders (turquoise) with their longitudinal axes organized in a triangular arrangement. Six rods composed of six phycocyanin cylinders (blue) are attached to the core. The light energy efficiently captured by the phycobilosme antenna is then transferred to the reaction centers of the photosystems II (PS II) and I (PS I). This illustration is based on the model suggested by Watanabe et al. [40].

to the controversial "early diverging" split of glaucophytes from the Archaeplastida stem [114,117] and suggest that the "red" and "green" three-helix LHC families probably evolved from SEP-like paralogues just after the presumed separation of the glaucophyte lineage. The remarkable diversity of the extended LHC protein superfamily in the Archaeplastida depicts a very complex evolutionary scenario that presumably involved numerous gene and domain duplications.

\section{The peptidoglycan wall of the glaucophyte plastid}

Peptidoglycan, or murein, is a hetero-polymer composed of chains of monosaccharides ( $N$-acetylmuramic acid and $\mathrm{N}$-acetylglucosamine) cross-linked by short peptide chains (3-5 amino acid residues). It forms a mesh surrounding the plasma membrane of most bacteria $[118,119]$. The rigidity of the peptidoglycan cell wall counteracts the osmotic pressure of the cytoplasm, preserving the cell integrity; the peptidoglycan cell wall also participates in bacterial division [118].

The peptidoglycan of the glaucophyte plastid PGW [120] is characterized by the presence of $\mathrm{N}$-acetylputrescine as the chemical substituent in half of the 1-carboxyl groups of the glutamic acid residues of the peptide chains [121,122]. Experimental studies have demonstrated that the biosynthesis of the peptidoglycan precursor (UDP- $N$-acetylmuramylpentapeptide) occurs in the glaucophyte plastid stroma, and that the assembly of the polymer network occurs in the periplasmic space $[60,123]$. The vast majority of the enzymes typically involved in peptidoglycan synthesis are not encoded in the Cyanophora plastid genome (with the exception of the putative lipid flippase FtsW) and they must be imported into the photosynthetic organelle [60,123]. As predicted [123], the Cyanophora paradoxa nuclear genome encodes numerous enzymes (at least 19) that presumably participate in peptidoglycan biosynthesis, with some of these sequences possessing putative transit- and signal- peptides characteristic of plastid-targeted proteins that will be imported into the periplasmic space [63]. The identified genes encode homologs of most of the enzymes involved in the synthesis of the stromal precursors UDP- $N$-acetylmuramylpentapeptide and UDP-N-acetylglucosamine (murA-F), production of the lipid-linked intermediaries Lipid I and Lipid II ( $m u r G, m r a Y$ ), as well as several penicillin-binding proteins (PBPs) that catalyze polymerization and crosslinking of the glycan strands $[8,63]$. As occurs frequently in plastid-localized pathways, the evolutionary history of peptidoglycan biosynthesis involves protein losses and replacements: not all the putative plastid-targeted enzymes have a cyanobacterial origin, suggesting that enzymes from other bacteria, presumably acquired via HGT, were recruited during the evolution of the glaucophyte plastid proteome [63].

During plastid division in glaucophytes the PGW forms the dividing septum that leads the membrane invagination in early steps of organelle division [124]. This role of the PGW was demonstrated by the inhibitory effect of diverse antibiotics (peptidoglycan biosynthesis inhibitors) on glaucophyte plastid division [125-127]. Due to the presence of the peptidoglycan layer, the molecular mechanisms for plastid division in glaucophytes are different from those of plastids from other members of the Archaeplastida. In red algal and viridiplant photosynthetic organelles two annular macromolecular structures are typically observed: the cytosolic plastid-dividing ring on the cytosolic side of the outer membrane and the stromal ring on the stromal side of the inner membrane [128]. In contrast, glaucophyte plastid division involves only a single stromal structure called "cyanelle ring", which is presumably a homolog of the "red" and "green" stromal ring. The dynamin-related protein 
DRP5B and the glycosyltransferase PDR1 (plastid dividing ring 1), which are involved in the synthesis of the cytosolic plastid-dividing ring in red algae and viridiplants, are not encoded in the Cyanophora genome [129]. The cytosolic ring possibly evolved as a mechanical replacement of the peptidoglycan septum after the loss of the PGW in red algae and viridiplants [127]. Even though the presence of a PGW has not been reported in viridiplant plastids, several enzymes involved in peptidoglycan biosynthesis are still encoded in the genomes of some land plants and actively participate in plastid division in mosses [129].

\section{Carboxysome-like structures in glaucophyte plastids}

Early immunoelectron microscopy studies demonstrated that electron dense structures surrounded by thylakoids in diverse glaucophytes (Fig. 2) $[54,56,78,130]$ contained high concentrations of the enzyme ribulose 1,5-bisphosphate carboxylase/oxygenase (RuBisCO), resembling the appearance of carboxysomes found in cyanobacteria [131]. Carboxysomes are bacterial microcompartments that accumulate RuBisCO and other enzymes within a protein shell and constitute part of the $\mathrm{CO}_{2}$-concentrating mechanisms $\left(\mathrm{CO}_{2}\right.$-CMs) that increase the catalytic efficiency of the RuBisCO carboxylation reaction $\left(\mathrm{RuBP}+\mathrm{CO}_{2} \rightarrow 2\right.$ molecules of 3-phosphoglycerate) [131,132]. Similarly, many photosynthetic eukaryotes with plastid-based $\mathrm{CO}_{2}-\mathrm{CMs}$ accumulate RuBisCO molecules in microcompartments called pyrenoids. In contrast to carboxysomes, pyrenoids do not have a protein shell. There are also basic ultrastructural differences between carboxysomes and pyrenoids, as the latter are often traversed by thylakoids whereas carboxysomes are not penetrated by membrane components [61]. As with carboxysomes, pyrenoid-based $\mathrm{CO}_{2}$ - $\mathrm{CMs}$ generate a localized increase in $\mathrm{CO}_{2}$ concentration in the proximity of the accumulated RuBisCO molecules increasing the catalytic efficiency of the RuBisCO carboxylation reaction while limiting the competing oxygenation reaction (RuBP $+\mathrm{O}_{2} \rightarrow$ 3-phosphoglycerate +2 -phosphoglycolate) [133] Physiological experiments and gene expression data from Cyanophora suggest that the glaucophyte carboxysome-like bodies (CLBs) are indeed part of an inducible $\mathrm{CO}_{2}-\mathrm{CM}$ apparatus $[132,134]$. Interestingly, the Cyanophora CLBs have no apparent protein shells, similar to eukaryotic pyrenoids, but are not traversed by thylakoids, similar in this respect to cyanobacterial carboxysomes.

It has been hypothesized that the co-occurrence of both the CLBs and the PGW in glaucophyte plastids is the evolutionary outcome of their reciprocal role in a putative carboxysome-based $\mathrm{CO}_{2}-\mathrm{CM}$ [135]. Importantly, this hypothesis posits that if the glaucophyte CLBs are carboxysomes, then high concentrations (higher than in other plastid $\left.\mathrm{CO}_{2}-\mathrm{CM}\right)$ of inorganic carbon $\left(\mathrm{HCO}_{3}{ }^{-}\right)$would be present inside the plastid [135]. This putative high concentration of $\mathrm{HCO}_{3}{ }^{-}$in the glaucophyte plastid stroma would produce significant differences between the osmolarities of the cytosol and the plastid interior, compromising the integrity of the organelle membranes. Consequently, the presence of a rigid plastid PGW would be a critical low-energy-cost mechanism to stabilize the volume and membranes of the glaucophyte hyperosmotic plastids [135]. In contrast, photosynthetic eukaryotes with pyrenoid-based $\mathrm{CO}_{2}$-CMs and plastids lacking a PGW have evolved active energy-dependent water efflux mechanisms (i.e., membrane solute co-transporters and channels) to cope with osmotic stress [135]. To our knowledge there are no direct data comparing glaucophyte plastid osmolarity levels to levels in plastids with pyrenoids. Further physiological investigations are required to explore important aspects of this hypothesis.

The ultrastructural similarities of the Cyanophora CLBs with both cyanobacterial carboxysomes and eukaryotic pyrenoids have raised questions about the specific biochemical mechanisms of the Cyanophora $\mathrm{CO}_{2}-\mathrm{CM}[61,63]$. Further, it has been questioned whether the Cyanophora CLBs are in fact bona fide carboxysomes, as key components of typical carboxysomes, such as genes for the proteins forming the semi-permeable shell that encapsulates RuBisCO and plastid-targeted carbonic anhydrases, are not present in the Cyanophora genome $[8,61]$. The absence of these typical carboxysome components suggests that the Cyanophora CLBs are possibly pyrenoid-like compartments $[61,63]$. Interestingly, there are also apparent structural differences between the CLBs of the different glaucophyte genera. For example, in the case of Gloeochaete and Cyanoptyche it is possible to distinguish CLBs with regular polyhedral shapes, presumably surrounded by protein shell-like structures (Fig. 2a), whereas in Glaucocystis (Fig. 2b) the CLBs has relatively irregular shape consistent with the absence of carboxysome shell proteins [63]. These ultrastructural data suggest that some structural, and possibly functional, divergence between the cyanobacterial-like CLBs (in Gloeochaete and Cyanoptyche) and the pyrenoid-like forms (those of Cyanophora and Glaucocystis) has occurred during glaucophyte evolution [63]. It remains to be investigated if these structural differences are related to functional peculiarities in the $\mathrm{CO}_{2}$ concentrating mechanisms of the different glaucophyte lineages.

\section{The glaucophyte mitochondrial genomes}

Complete mitochondrial genomes (mtDNAs) are now available for four glaucophyte species from four different genera: Cyanophora paradoxa (strain UTEX LB 555) and Glaucocystis nostochinearum (UTEX 64) [8], and Cyanoptyche gloeocystis (strain SAG 4.97) and Gloeochaete wittrockiana (SAG 48.84) [10]. Similar to the mtDNA of many Archaeplastida, glaucophyte mtDNAs are circular-mapping with no apparent unusual gene or genome structures (Fig. 6a). The mtDNA gene complement is very similar across the different genera and comparable to the most gene-rich mtDNAs known in green and red algae [8] (Tab. 3). It includes genes for transfer RNAs (tRNAs) that are capable of servicing all the codons in the mitochondrial genes, with the exception of ACN codons (threonine). The Gloeochaete wittrockiana and Glaucocystis nostochinearum mtDNAs lack a tRNA to decode ACA and ACG codons, whereas Cyanophora paradoxa and Cyanoptyche gloeocystis lack trnT genes entirely. Therefore, glaucophytes might rely on import of cytoplasmic trnT, or differential RNA editing of the anticodon might produce two tRNAs from a single mitochondrial gene as reported in opossum [136]. No 5S ribosomal RNA gene (rrn5) was 
a
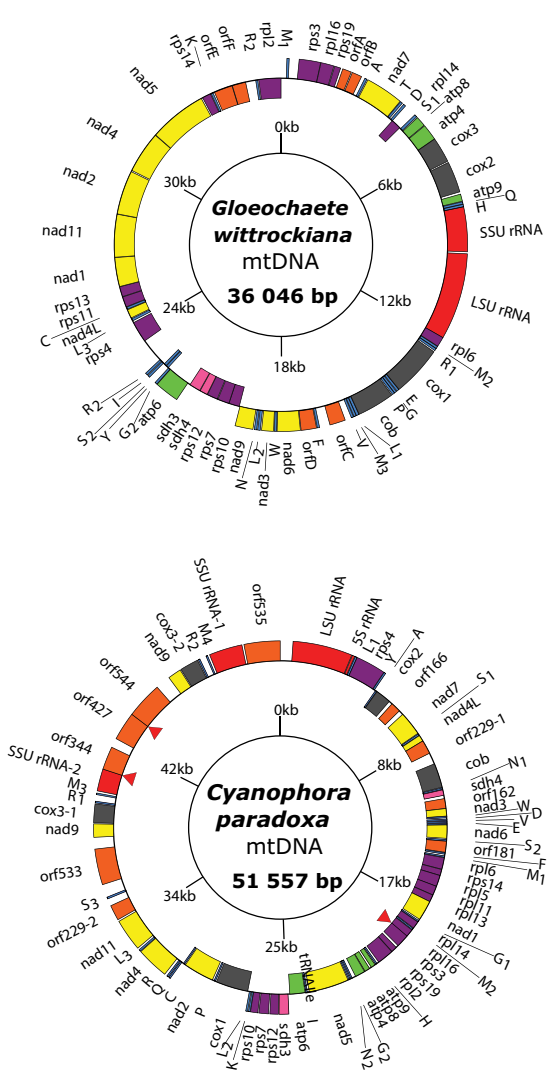
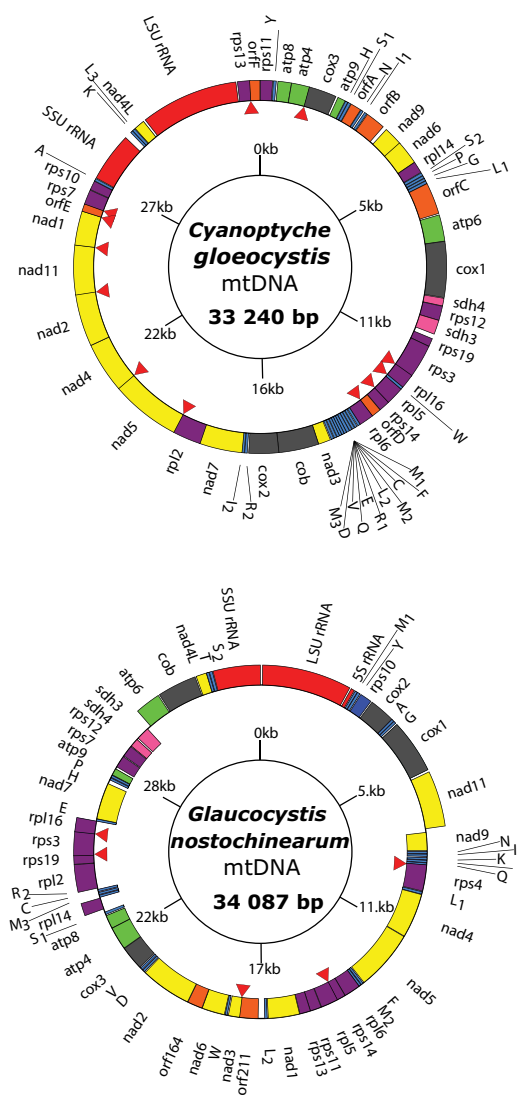

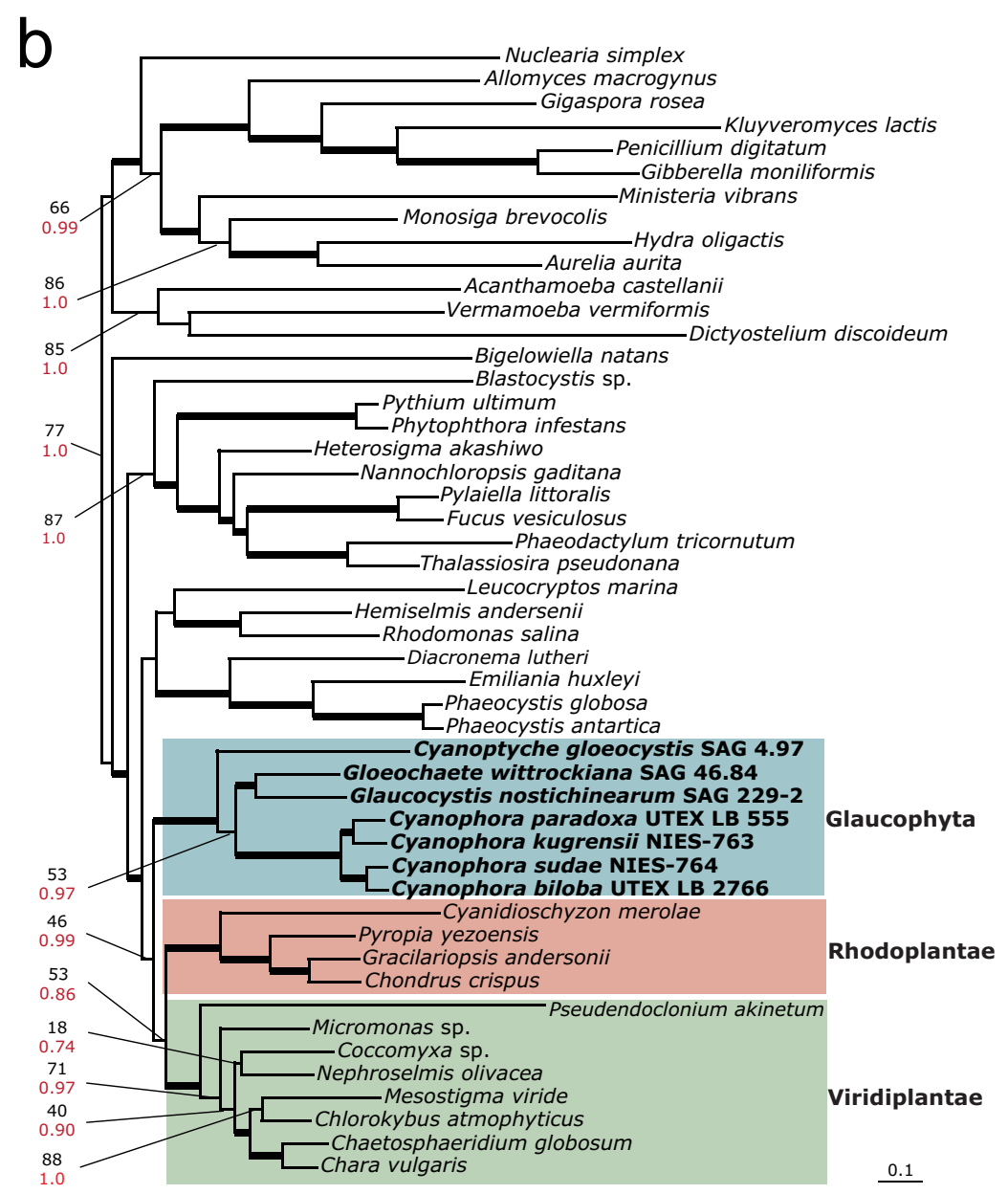


Fig. 6 Mitochondrial genomes of Glaucophyta. a Circular maps of the Gloeochaeate wittrockiana, Cyanoptyche gloeocystis, Cyanophora paradoxa and Glaucocystis nostochinearum mitochondrial genomes. Color bars identify types of genes/ORFs: ribosomal RNAs (red), transfer RNA genes (blue), ribosomal proteins (purple), complex I (yellow), complex II (pink), complex III and IV (dark gray), complex V (green), unidentified ORFs (orange). Red arrowheads indicate overlaps between genes. Note that all Cyanoptyche gloeocystis genes are encoded in the same DNA strand. b ML phylogenetic tree estimated from conceptual translations of the mitochondrial genes atp6, atp9, cob, cox 1, cox2, cox3, nad1, nad2, nad3, nad4, nad4L, nad5, nad6 and nad7. Numbers in black represent bootstrap proportion support (BS) and values in red are Bayesian posterior probabilities (PP), respectively. The phylogenetic tree was arbitrarily rooted defining the "unikont" (i.e., opisthokonts and amoebozoans) lineages as outgroup. Thick branches are supported by both BS and PP values $>95$. Branch lengths are proportional to the number of substitutions per site indicated with scale bar (see Jackson and Reyes-Prieto [10] for detailed methods).

Tab. 3 Characteristics of glaucophyte mitochondrial genomes.

\begin{tabular}{lcccc}
\hline & $\begin{array}{c}\text { Cyanoptyche } \\
\text { gloeocystis }\end{array}$ & $\begin{array}{c}\text { Gloeochaete } \\
\text { wittrockiana }\end{array}$ & $\begin{array}{c}\text { Cyanophora } \\
\text { paradoxa }\end{array}$ & $\begin{array}{c}\text { Glaucocystis } \\
\text { nostochinearum }\end{array}$ \\
\hline Size (kb) & 33.24 & 36.05 & 51.6 & 34.1 \\
Shape (map) & circular & circular & circular & circular \\
Protein coding genes & 33 & 33 & 34 & 34 \\
Unidentified ORFs & 6 & 6 & 10 & 2 \\
23S rRNA & 1 & 1 & 1 & 1 \\
16S rRNA & 1 & 1 & 1 & 1 \\
5S rRNA & 1 & not detected & 1 & 1 \\
Transfer RNAs & 23 & 26 & 24 & 23 \\
A + T content (\%) & 71.5 & 69.5 & 74.0 & 74.3 \\
Intergenic sequence (\%) & 3.9 & 7.4 & 15.3 & 5.3 \\
Genetic code & standard & standard & standard & standard \\
\hline
\end{tabular}

detected in the Gloeochaete wittrockiana mtDNA using different approaches [10,137]. A single group I intron is present in the Cyanoptyche gloeocystis large subunit rRNA gene, whereas no introns have been detected for any gene in any other glaucophyte species [10].

An unusual feature of Cyanophora paradoxa mtDNA genes is the exceptionally high substitution rate they have undergone, relative to plastid and nuclear genes. Comparison of synonymous-site divergence in two Cyanophora paradoxa isolates (strains UTEX LB 555 and NIES-763; the latter now renamed as Cyanophora kugrensii [39]) reveals a substitution rate $4-5$-fold higher in mtDNA genes compared to those in the other two genomic compartments [37]. This pattern is consistent with data from other Archaeplastida lineages, where (with the exception of most seed-plants) the mtDNA mutation rate is usually similar to or higher than the ptDNA mutation rate. Only limited conclusions can be drawn at present, however, as sufficient sequence data from all three genomes is only available from a small number of taxa.

As noted above, substantial evidence suggests that the glaucophytes, red algae and viridiplants share a common ancestor, but some phylogenetic analyses do not recover these three lineages as a monophyletic clade. Multi-locus phylogenetic analyses using mtDNA genes from a broad sample of major eukaryote lineages, including data from seven glaucophytes (four Cyanophora species/strains, Gloeochaete wittrockiana, Glaucocystis nostochinearum and Cyanoptyche gloeocystis), do recover a clade uniting the three Archaeplastida groups with high Bayesian posterior probability but maximum-likelihood bootstrap support $<50 \%$ [10] (Fig. 6b). This recovery is dependent on the expanded glaucophyte taxon sampling undertaken in the study. The Archaeplastida monophyly is resolved only when excavates sequences (i.e. jakobids, malawimonads and the long-branch heterolobosean Naegleria) are excluded from the phylogenetic analysis [10].

\section{Concluding remarks: perspectives on glaucophyte research}

A central aim behind the sequencing of a glaucophyte nuclear genome was to test different hypotheses regarding the putative common origin of red algae, viridiplants and glaucophytes. The phylogenetic survey of the Cyanophora genome has certainly provided some support for the monophyly of Archaeplastida, but the small glaucophyte sample in most phylogenetic trees (just a single species) is still a limiting factor in providing conclusive answers. Phylogenetic analyses using mitochondrial genes have demonstrated the importance of a large glaucophyte taxon sampling in multilocus analyses when testing the Archaeplastida monophyly, emphasizing that further research efforts in that direction should rely on a broader genomic knowledge base of diverse glaucophyte taxa. 
Recent studies of species diversity in glaucophytes have provided a new perspective to investigate the overall diversity of the group. Some important questions that require answers are: what are the phylogenetic relationships among the known genera? What is the level of species diversity within the poorly studied genera Cyanoptyche and Gloeochaete? Are the genomic and physiological repertoires of different glaucophyte genera similar? Some current efforts are employing high-throughput strategies, such as fluorescence activated cell sorting (FACS) and environmental genomics, to investigate glaucophyte diversity, abundance and geographic distribution. For example, the possible presence of glaucophytes in marine environments is being explored.

\section{Acknowledgments}

Susan Belfry (Microscopy and Microanalysis Facility, University of New Brunswick, Fredericton) for preparation of the transmission electron microscopy samples and images. We also acknowledge the constructive criticisms and excellent suggestions of several anonymous reviewers and the ASBP editor Andrzej Bodył.

\section{Authors' contributions}

The following declarations about authors' contributions to the research have been made: conceived and wrote the majority of the manuscript: ARP; contributed sections about plastid and mitochondrial genomics: CJ; wrote the section on genera: SC; CJ and SC assisted with manuscript revisions and figure preparation; ARP reviewed and approved the final version of the manuscript.

\section{Competing interests}

No competing interests have been declared.

\section{References}

1. Skuja H. Glaucophyta. In: Melchior H, Werdermann E, editors. A. Engler's Syllabus der Pflanzenfamilien. Berlin: Borntraeger; 1954. p. 56-57.

2. Kies L, Kremer BP. Typification of the Glaucocystophyta. Taxon. 1986;35(1):128-133. http://dx.doi.org/10.2307/1221049

3. Cavalier-Smith T. Eukaryote kingdoms: seven or nine? Biosystems. 1981;14(3-4):461-481. http://dx.doi.org/10.1016/0303-2647(81)90050-2

4. Adl SM, Simpson AGB, Farmer MA, Andersen RA, Anderson OR, Barta JR, et al. The new higher level classification of eukaryotes with emphasis on the taxonomy of protists. J Eukaryot Microbiol. 2005;52(5):399451. http://dx.doi.org/10.1111/j.1550-7408.2005.00053.x

5. Rodríguez-Ezpeleta N, Brinkmann H, Burey SC, Roure B, Burger G, Löffelhardt W, et al. Monophyly of primary photosynthetic eukaryotes: green plants, red algae, and glaucophytes. Curr Biol. 2005;15(14):13251330. http://dx.doi.org/10.1016/j.cub.2005.06.040

6. Burki F, Inagaki Y, Bråte J, Archibald JM, Keeling PJ, Cavalier-Smith $\mathrm{T}$, et al. Large-scale phylogenomic analyses reveal that two enigmatic protist lineages, Telonemia and Centroheliozoa, are related to photosynthetic chromalveolates. Genome Biol Evol. 2009;1:231-238. http:// dx.doi.org/10.1093/gbe/evp022

7. Hackett JD, Yoon HS, Li S, Reyes-Prieto A, Rummele SE, Bhattacharya D. Phylogenomic analysis supports the monophyly of cryptophytes and haptophytes and the association of Rhizaria with chromalveolates. Mol Biol Evol. 2007;24(8):1702-1713. http://dx.doi.org/10.1093/ $\mathrm{molbev} / \mathrm{msm} 089$

8. Price DC, Chan CX, Yoon HS, Yang EC, Qiu H, Weber APM, et al. Cyanophora paradoxa genome elucidates origin of photosynthesis in algae and plants. Science. 2012;335(6070):843-847. http://dx.doi. org/10.1126/science.1213561

9. Qiu H, Yang EC, Bhattacharya D, Yoon HS. Ancient gene paralogy may mislead inference of plastid phylogeny. Mol Biol Evol. 2012;29(11):3333-3343. http://dx.doi.org/10.1093/molbev/mss137
Other important directions for further research have been identified after recent comparative investigations. These include studies to understand the function of the glaucophyte photosynthetic apparatus in the absence of typical LHC proteins, investigations of the physiological roles of the peculiar phytochromes found in Cyanophora and Gloeochaete, and analyses of the biochemical characteristics of the plastid $\mathrm{CO}_{2}$-CMs from diverse glaucophyte species to untangle the carboxysome versus pyrenoid debate. The recent findings in diverse research areas have considerably expanded our knowledge of glaucophytes and motivated comprehensive studies of the basic biology of this poorly studied, but fascinating, algal group.

10. Jackson CJ, Reyes-Prieto A. The mitochondrial genomes of the glaucophytes Gloeochaete wittrockiana and Cyanoptyche gloeocystis: multilocus phylogenetics suggests a monophyletic Archaeplastida. Genome Biol Evol. 2014;6(10):2774-2785. http://dx.doi.org/10.1093/ gbe/evu 218

11. Kim E, Graham LE. EEF2 analysis challenges the monophyly of Archaeplastida and Chromalveolata. PLoS One. 2008;3(7):e2621. http://dx.doi.org/10.1371/journal.pone.0002621

12. Hampl V, Hug L, Leigh JW, Dacks JB, Lang BF, Simpson AGB, et al. Phylogenomic analyses support the monophyly of Excavata and resolve relationships among eukaryotic "supergroups". Proc Natl Acad Sci USA. 2009;106(10):3859-3864. http://dx.doi.org/10.1073/ pnas.0807880106

13. Nozaki H, Maruyama S, Matsuzaki M, Nakada T, Kato S, Misawa K. Phylogenetic positions of Glaucophyta, green plants (Archaeplastida) and Haptophyta (Chromalveolata) as deduced from slowly evolving nuclear genes. Mol Phylogenet Evol. 2009;53(3):872-880. http://dx.doi. org/10.1016/j.ympev.2009.08.015

14. Stiller JW. Plastid endosymbiosis, genome evolution and the origin of green plants. Trends Plant Sci. 2007;12(9):391-396. http://dx.doi. org/10.1016/j.tplants.2007.08.002

15. Parfrey LW, Barbero E, Lasser E, Dunthorn M, Bhattacharya D, Patterson DJ, et al. Evaluating support for the current classification of eukaryotic diversity. PLoS Genet. 2006;2(12):e220. http://dx.doi. org/10.1371/journal.pgen.0020220

16. Burki F, Okamoto N, Pombert JF, Keeling PJ. The evolutionary history of haptophytes and cryptophytes: phylogenomic evidence for separate origins. Proc Biol Sci. 2012;279(1736):2246-2254. http:// dx.doi.org/10.1098/rspb.2011.2301

17. Yabuki A, Kamikawa R, Ishikawa SA, Kolisko M, Kim E, Tanabe AS, et al. Palpitomonas bilix represents a basal cryptist lineage: insight into the character evolution in Cryptista. Sci Rep. 2014;4:4641. http:// dx.doi.org/10.1038/srep04641

18. Deschamps P, Moreira D. Signal conflicts in the phylogeny of the primary photosynthetic eukaryotes. Mol Biol Evol. 2009;26(12):27452753. http://dx.doi.org/10.1093/molbev/msp189

19. Mackiewicz P, Gagat P. Monophyly of Archaeplastida supergroup and relationships among its lineages in the light of phylogenetic and phylogenomic studies. Are we close to a consensus? Acta Soc Bot Pol. 2014;83(4):263-280. http://dx.doi.org/10.5586/asbp.2014.044

20. Parfrey LW, Grant J, Tekle YI, Lasek-Nesselquist E, Morrison HG, Sogin ML, et al. Broadly sampled multigene analyses yield a wellresolved eukaryotic tree of life. Syst Biol. 2010;59(5):518-533. http:// dx.doi.org/10.1093/sysbio/syq037

21. Lane CE, Archibald JM. The eukaryotic tree of life: endosymbiosis takes its TOL. Trends Ecol Evol. 2008;23(5):268-275. http://dx.doi. org/10.1016/j.tree.2008.02.004

22. Ball SG, Subtil A, Bhattacharya D, Moustafa A, Weber APM, Gehre L, et al. Metabolic effectors secreted by bacterial pathogens: essential 
facilitators of plastid endosymbiosis? Plant Cell. 2013;25(1):7-21. http://dx.doi.org/10.1105/tpc.112.101329

23. Elias M. The guanine nucleotide exchange factors Sec2 and PRONE: candidate synapomorphies for the Opisthokonta and the Archaeplastida. Mol Biol Evol. 2008;25(8):1526-1529. http://dx.doi.org/10.1093/ molbev/msn 113

24. Cavalier-Smith T. The origins of plastids. Biol J Linn Soc. 1982;17(3):289-306. http://dx.doi.org/10.1111/j.1095-8312.1982. tb02023.x

25. Palmer JD. The symbiotic birth and spread of plastids: how many times and whodunit? J Phycol. 2003;39(1):4-12. http://dx.doi. org/10.1046/j.1529-8817.2003.02185.x

26. Reyes-Prieto A, Weber AP, Bhattacharya D. The origin and establishment of the plastid in algae and plants. Annu Rev Genet. 2007;41:147168. http://dx.doi.org/10.1146/annurev.genet.41.110306.130134

27. Keeling PJ. The endosymbiotic origin, diversification and fate of plastids. Philos Trans R Soc Lond B Biol Sci. 2010;365(1541):729-748. http://dx.doi.org/10.1098/rstb.2009.0103

28. Gould SB, Waller RF, McFadden GI. Plastid evolution. Annu Rev Plant Biol. 2008;59:491-517. http://dx.doi.org/10.1146/annurev. arplant.59.032607.092915

29. Stoebe B, Kowallik KV. Gene-cluster analysis in chloroplast genomics. Trends Genet. 1999;15(9):344-347. http://dx.doi.org/10.1016/ S0168-9525(99)01815-6

30. Reyes-Prieto A, Bhattacharya D. Phylogeny of Calvin cycle enzymes supports Plantae monophyly. Mol Phylogenet Evol. 2007;45(1):384391. http://dx.doi.org/10.1016/j.ympev.2007.02.026

31. Reyes-Prieto A, Moustafa A. Plastid-localized amino acid biosynthetic pathways of Plantae are predominantly composed of non-cyanobacterial enzymes. Sci Rep. 2012;2:955. http://dx.doi.org/10.1038/srep00955

32. McFadden GI, van Dooren GG. Evolution: red algal genome affirms a common origin of all plastids. Curr Biol. 2004;14(13):R514-R516. http://dx.doi.org/10.1016/j.cub.2004.06.041

33. Steiner JM, Yusa F, Pompe JA, Löffelhardt W. Homologous protein import machineries in chloroplasts and cyanelles. Plant J. 2005;44(4):646652. http://dx.doi.org/10.1111/j.1365-313X.2005.02559.x

34. Linka N, Hurka H, Lang BF, Burger G, Winkler HH, Stamme C, et al. Phylogenetic relationships of non-mitochondrial nucleotide transport proteins in bacteria and eukaryotes. Gene. 2003;306:27-35. http:// dx.doi.org/10.1016/S0378-1119(03)00429-3

35. Stiller JW. Toward an empirical framework for interpreting plastid evolution. J Phycol. 2014;50(3):462-471. http://dx.doi.org/10.1111/ jpy. 12178

36. Kim E, Maruyama S. A contemplation on the secondary origin of green algal and plant plastids. Acta Soc Bot Pol. 2014;83(4):331-336. http://dx.doi.org/10.5586/asbp.2014.040

37. Smith DR, Jackson CJ, Reyes-Prieto A. Nucleotide substitution analyses of the glaucophyte Cyanophora suggest an ancestrally lower mutation rate in plastid vs mitochondrial DNA for the Archaeplastida. Mol Phylogenet Evol. 2014;79:380-384. http://dx.doi.org/10.1016/j. ympev.2014.07.001

38. Chong J, Jackson C, Kim JI, Yoon HS, Reyes-Prieto A. Molecular markers from different genomic compartments reveal cryptic diversity within glaucophyte species. Mol Phylogenet Evol. 2014;76C:181-188. http://dx.doi.org/10.1016/j.ympev.2014.03.019

39. Takahashi T, Sato M, Toyooka K, Matsuzaki R, Kawafune K, Kawamura $\mathrm{M}$, et al. Five Cyanophora (Cyanophorales, Glaucophyta) species delineated based on morphological and molecular data. J Phycol. 2014;50(6):1058-1069. http://dx.doi.org/10.1111/jpy.12236

40. Watanabe M, Sato M, Kondo K, Narikawa R, Ikeuchi M. Phycobilisome model with novel skeleton-like structures in a glaucocystophyte $C y$ anophora paradoxa. Biochim Biophys Acta. 2012;1817(8):1428-1435. http://dx.doi.org/10.1016/j.bbabio.2011.11.013

41. Facchinelli F, Pribil M, Oster U, Ebert NJ, Bhattacharya D, Leister $\mathrm{D}$, et al. Proteomic analysis of the Cyanophora paradoxa muroplast provides clues on early events in plastid endosymbiosis. Planta. 2013;237(2):637-651. http://dx.doi.org/10.1007/s00425-012-1819-3

42. Ball S, Colleoni C, Cenci U, Raj JN, Tirtiaux C. The evolution of glycogen and starch metabolism in eukaryotes gives molecular clues to understand the establishment of plastid endosymbiosis. J Exp Bot. 2011;62(6):1775-1801. http://dx.doi.org/10.1093/jxb/erq411

43. Watanabe $M$, Kubota $H$, Wada $H$, Narikawa R, Ikeuchi M. Novel supercomplex organization of photosystem I in Anabaena and Cyanophora paradoxa. Plant Cell Physiol. 2011;52(1):162-168. http:// dx.doi.org/10.1093/pcp/pcq183

44. Gross J, Wajid S, Price DC, Zelzion E, Li J, Chan CX, et al. Evidence for widespread exonic small RNAs in the glaucophyte alga Cyanophora paradoxa. PLoS One. 2013;8(7):e67669. http://dx.doi.org/10.1371/ journal.pone.0067669

45. Duanmu D, Bachy C, Sudek S, Wong CH, Jimenez V, Rockwell NC, et al. Marine algae and land plants share conserved phytochrome signaling systems. Proc Natl Acad Sci USA. 2014;11(44):15827-15832. http://dx.doi.org/10.1073/pnas.1416751111

46. Rockwell NC, Duanmu D, Martin SS, Bachy C, Price DC, Bhattacharya D, et al. Eukaryotic algal phytochromes span the visible spectrum. Proc Natl Acad Sci USA. 2014;111(10):3871-3876. http://dx.doi. org/10.1073/pnas.1401871111

47. Bhattacharya D, Schmidt HA. Division Glaucocystophyta. In: Bhattacharya D, editor. Origins of algae and their plastids. Plant systematics and evolution - supplement 11. Vienna: Springer Verlag; 1997. p. 139-148. http://dx.doi.org/10.1007/978-3-7091-6542-3_7

48. Yang Y, Maruyama S, Sekimoto H, Sakayama H, Nozaki H. An extended phylogenetic analysis reveals ancient origin of "non-green" phosphoribulokinase genes from two lineages of "green" secondary photosynthetic eukaryotes: Euglenophyta and Chlorarachniophyta. BMC Res Notes. 2011;4:330. http://dx.doi.org/10.1186/1756-0500-4-330

49. Marin B, Klingberg M, Melkonian M. Phylogenetic relationships among the Cryptophyta: analyses of nuclear-encoded SSU rRNA sequences support the monophyly of extant plastid-containing lineages. Protist. 1998;149(3):265-276. http://dx.doi.org/10.1016/ S1434-4610(98)70033-1

50. Burki F, Shalchian-Tabrizi K, Pawlowski J. Phylogenomics reveals a new "megagroup" including most photosynthetic eukaryotes. Biol Lett. 2008;4(4):366-369. http://dx.doi.org/10.1098/rsbl.2008.0224

51. Pascher A. Studien über Symbiosen. I. Über einige Endosymbiosen von Blaualgen in Einzellern. Jahrb Wss Bot. 1929;71:286-462.

52. Schenk HEA. Cyanophora paradoxa: anagenetic model or missing link of plastid evolution. Endocytobiosis Cell Res. 1994;10:87-106.

53. Chapman DJ. The pigments of the symbiotic algae (cyanomes) of Cyanophora paradoxa and Glaucocystis nostochinearum and two Rhodophyceae, Porphyridium aerugineum and Asteroeytis ramosa. Arch fur Mikrobiol. 1966;55:17-25. http://dx.doi.org/10.1007/BF00409152

54. Hall W. T, Claus G. Ultrastructural studies on the blue-green algal symbiont in Cyanophora paradoxa Korschikoff. J Cell Biol. 1963;19:551563. http://dx.doi.org/10.1083/jcb.19.3.551

55. Herdman M, Stanier RY. The cyanelle: chloroplast or endosymbiotic prokaryote? FEMS Microbiol Lett. 1977;1(1):7-11. http://dx.doi. org/10.1111/j.1574-6968.1977.tb00568.x

56. Kies L. Zur systematischen Einordnung von Cyanophora paradoxa, Gloeochaete wittrockiana und Glaucocystis nostochinearum. Ber Dtsch Bot Ges. 1979;92(1):445-454. http://dx.doi. org/10.1111/j.1438-8677.1979.tb03291.x

57. Giovannoni SJ, Turner S, Olsen GJ, Barns S, Lane DJ, Pace NR. Evolutionary relationships among cyanobacteria and green chloroplasts. J Bacteriol. 1988;170(8):3584-3592.

58. Douglas SE, Turner S. Molecular evidence for the origin of plastids from a cyanobacterium-like ancestor. J Mol Evol. 1991;33(3):267-273. http://dx.doi.org/10.1007/BF02100678

59. Stirewalt VL, Michalowski CB, Löffelhardt W, Bohnert HJ, Bryant DA. Nucleotide sequence of the cyanelle genome from Cyanophora paradoxa. Plant Mol Biol Report. 1995;13(4):327-332. http://dx.doi. org/10.1007/BF02669186 
60. Löffelhardt W, Bohnert HJ. The cyanelle (muroplast) of Cyanophora paradoxa: a paradigm for endosymbiotic organelle evolution. In: Seckbach J, editor. Symbiosis. Mechanisms and model systems. Cellular origin, Life in extreme habitats and astrobiology. Volume 4. Dordrecht: Kluwer Academic Publishers; 2001. p. 111-130. http:// dx.doi.org/10.1007/0-306-48173-1_7

61. Fathinejad S, Steiner JM, Reipert S, Marchetti M, Allmaier G, Burey SC, et al. A carboxysomal carbon-concentrating mechanism in the cyanelles of the "coelacanth" of the algal world, $C y$ anophora paradoxa? Physiol Plant. 2008;133(1):27-32. http://dx.doi. org/10.1111/j.1399-3054.2007.01030.x

62. Steiner JM, Löffelhardt W. The photosynthetic apparatus of the living fossil, Cyanophora paradoxa. In: Peschek GA, Obinger C, Renger $G$, editors. Bioenergetic processes of cyanobacteria. Dordrecht: Springer Netherlands; 2011. p. 71-87. http://dx.doi. org/10.1007/978-94-007-0388-9_2

63. Bhattacharya D, Price DC, Gross J, Chan CX, Steiner JM, Löffelhardt W. Analysis of the genome of Cyanophora paradoxa: an algal model for understanding primary endosymbiosis. In: Löffelhardt W, editor. Endosymbiosis. Vienna: Springer; 2014. p. 135-148. http://dx.doi. org/10.1007/978-3-7091-1303-5_7

64. Lauterborn R. Protozoenstudien II. Paulinella chromatophora nov. gen., nov. spec., ein beschalter Rhizopode des Süsswassers mit blaugrünen chromatophorenartigen Einschlüssen. Zeitschrift für wissenschaftliche Zool. 1895;59:537-544.

65. Kies L. Elektronenmikroskopische Untersuchungen an Paulinella chromatophora Lauterborn, einer Thekamöbe mit blau-grünen Endosymbionten (Cyanellen). Protoplasma. 1974;80(1-3):69-89. http://dx.doi.org/10.1007/BF01666352

66. Marin B, Nowack ECM, Melkonian M. A plastid in the making: evidence for a second primary endosymbiosis. Protist. 2005;156(4):425432. http://dx.doi.org/10.1016/j.protis.2005.09.001

67. Mignot JP, Joyon L, Pringsheim EG. Quelques Particularités Structurales de Cyanophora paradoxa Korsch., Protozoaire Flagellé. J Protozool. 1969;16(1):138-145. http://dx.doi.org/10.1111/j.1550-7408.1969. tb02245.x

68. Thompson A. The flagella of Cyanophora paradoxa Korsch. S Afr J Bot. 1973;39:35-39.

69. Kugrens P, Clay BL, Meyer CJ, Lee RE. Ultrastructure and description of Cyanophora biloba, sp. nov., with additional observations on C. paradoxa (Glaucophyta). J Phycol. 1999;35(4):844-854. http:// dx.doi.org/10.1046/j.1529-8817.1999.3540844.x

70. Viola R, Nyvall P, Pedersén M. The unique features of starch metabolism in red algae. Proc Biol Sci. 2001;268(1474):1417-1422. http:// dx.doi.org/10.1098/rspb.2001.1644

71. Plancke C, Colleoni C, Deschamps P, Dauvillée D, Nakamura Y, Haebel S, et al. Pathway of cytosolic starch synthesis in the model glaucophyte Cyanophora paradoxa. Eukaryot Cell. 2008;7(2):247-257. http://dx.doi.org/10.1128/EC.00373-07

72. Nomura T, Nakayama N, Murata T, Akazawa T. Biosynthesis of starch in chloroplasts. Plant Physiol. 1967;42(3):327-332. http://dx.doi. org/10.1104/pp.42.3.327

73. Tester RF, Karkalas J, Qi X. Starch - composition, fine structure and architecture. J Cereal Sci. 2004;39(2):151-165. http://dx.doi. org/10.1016/j.jcs.2003.12.001

74. Shimonaga T, Fujiwara S, Kaneko M, Izumo A, Nihei S, Francisco $\mathrm{PB}$, et al. Variation in storage alpha-polyglucans of red algae: amylose and semi-amylopectin types in Porphyridium and glycogen type in Cyanidium. Mar Biotechnol. 2007;9(2):192-202. http://dx.doi. org/10.1007/s10126-006-6104-7

75. Hindak F, Hindakova A. Chalarodora azurea Pascher 1929 - a rare glaucophyte found in the peat-bog Klin (Orava, Northern Slovakia). In: Wołowski K, Kaczmarska I, Ehrman JM, Wojtal AZ, editors. Current advances in algal taxonomy and its applications: phylogenetic, ecological and applied perspective. Kraków: Institute of Botany, Polish Academy of Sciences; 2012. p. 53-60.

76. Willison JH, Brown RM. Cell wall structure and deposition in
Glaucocystis. J Cell Biol. 1978;77(1):103-119. http://dx.doi.org/10.1083/ jcb.77.1.103

77. Schnepf E, Koch W, Deichgraber G. Zur Cytologie und taxonomischen Einordnung von Glaucocystis. Arch Mikrobiol. 1966;55(2):149-174. http://dx.doi.org/10.1007/BF00418636

78. Kies L. Ultrastructure of Cyanoptyche gloeocystis $\mathrm{f}$. dispersa (Glaucocystophyceae). Plant Syst Evol. 1989;164(1-4):65-73. http://dx.doi. org/10.1007/BF00940430

79. Lagerheim G. Bidrag till Sveriges algflora. Öfversigt af Kongl. Vetenskaps-Akademiens Förhandlingar. 1883;40(2):37-78.

80. Korshikov A. Protistologische Beobachtungen. I Cyanophora paradoxa n. g. et sp. Russ Arch Protistol. 1924;3:57-74.

81. Reddy TBK, Thomas AD, Stamatis D, Bertsch J, Isbandi M, Jansson J, et al. The Genomes OnLine Database (GOLD) v.5: a metadata management system based on a four level (meta)genome project classification. Nucleic Acids Res. 2014; 43:D1099-D1106. http:// dx.doi.org/10.1093/nar/gku950

82. Collén J, Porcel B, Carré W, Ball SG, Chaparro C, Tonon T, et al. Genome structure and metabolic features in the red seaweed Chondrus crispus shed light on evolution of the Archaeplastida. Proc Natl Acad Sci USA. 2013;110(13):5247-5252. http://dx.doi.org/10.1073/ pnas. 1221259110

83. Schönknecht G, Chen WH, Ternes CM, Barbier GG, Shrestha RP, Stanke M, et al. Gene transfer from bacteria and archaea facilitated evolution of an extremophilic eukaryote. Science. 2013;339(6124):12071210. http://dx.doi.org/10.1126/science.1231707

84. Nakamura Y, Sasaki N, Kobayashi M, Ojima N, Yasuike M, Shigenobu $\mathrm{Y}$, et al. The first symbiont-free genome sequence of marine red alga, Susabi-nori (Pyropia yezoensis). PLoS One. 2013;8(3):e57122. http:// dx.doi.org/10.1371/journal.pone.0057122

85. Bhattacharya D, Price DC, Chan CX, Qiu H, Rose N, Ball S, et al. Genome of the red alga Porphyridium purpureum. Nat Commun. 2013;4:1941. http://dx.doi.org/10.1038/ncomms2931

86. Yusa F, Steiner JM, Löffelhardt W. Evolutionary conservation of dual Sec translocases in the cyanelles of Cyanophora paradoxa. BMC Evol Biol. 2008;8:304. http://dx.doi.org/10.1186/1471-2148-8-304

87. Gross J, Bhattacharya D. Mitochondrial and plastid evolution in eukaryotes: an outsiders' perspective Nat Rev Genet. 2009;10(7):495-505. http://dx.doi.org/10.1038/nrg2610

88. Stiller JW, Reel DC, Johnson JC. A single origin of plastids revisited: convergent evolution in organellar genome content. J Phycol. 2003;39(1):95-105. http://dx.doi. org/10.1046/j.1529-8817.2003.02070.x

89. Stiller JW. Weighing the evidence for a single origin of plastids. J Phycol. 2003;39(6):1283-1285. http://doi.wiley. com/10.1111/j.0022-3646.2003.03-084.x

90. Larkum AWD, Lockhart PJ, Howe CJ. Shopping for plastids. Trends Plant Sci. 2007;12(5):189-195. http://dx.doi.org/10.1016/j. tplants.2007.03.011

91. Suzuki K, Miyagishima SY. Eukaryotic and eubacterial contributions to the establishment of plastid proteome estimated by large-scale phylogenetic analyses. Mol Biol Evol. 2010;27(3):581-590. http:// dx.doi.org/10.1093/molbev/msp273

92. Qiu H, Price DC, Weber APM, Facchinelli F, Yoon HS, Bhattacharya D. Assessing the bacterial contribution to the plastid proteome. Trends Plant Sci. 2013;18(12):680-687. http://dx.doi.org/10.1016/j. tplants.2013.09.007

93. Huang J, Gogarten JP. Did an ancient chlamydial endosymbiosis facilitate the establishment of primary plastids? Genome Biol. 2007;8(6):R99. http://dx.doi.org/10.1186/gb-2007-8-6-r99

94. Moustafa A, Reyes-Prieto A, Bhattacharya D. Chlamydiae has contributed at least 55 genes to Plantae with predominantly plastid functions. PLoS One. 2008;3(5):e2205. http://dx.doi.org/10.1371/ journal.pone.0002205

95. Deschamps P. Primary endosymbiosis: have cyanobacteria and 
Chlamydiae ever been roommates? Acta Soc Bot Pol. 2014;83(4):291302. http://dx.doi.org/10.5586/asbp.2014.048

96. Facchinelli F, Colleoni C, Ball SG, Weber APM. Chlamydia, cyanobiont, or host: who was on top in the ménage à trois? Trends Plant Sci. 2013;18(12):673-679. http://dx.doi.org/10.1016/j.tplants.2013.09.006

97. Dagan T, Roettger M, Stucken K, Landan G, Koch R, Major P, et al. Genomes of Stigonematalean cyanobacteria (subsection $\mathrm{V}$ ) and the evolution of oxygenic photosynthesis from prokaryotes to plastids. Genome Biol Evol. 2013;5(1):31-44. http://dx.doi.org/10.1093/gbe/ evs 117

98. Flinner N, Ellenrieder L, Stiller SB, Becker T, Schleiff E, Mirus O. $\mathrm{Mdm} 10$ is an ancient eukaryotic porin co-occurring with the ERMES complex. Biochim Biophys Acta. 2013;1833(12):3314-3325. http:// dx.doi.org/10.1016/j.bbamcr.2013.10.006

99. Cai X, Wang X, Clapham DE. Early evolution of the eukaryotic $\mathrm{Ca}^{2+}$ signaling machinery: conservation of the CatSper channel complex. Mol Biol Evol. 2014;31(10):2735-2740. http://dx.doi.org/10.1093/ molbev/msu218

100. Petrželková R, Eliáš M. Contrasting patterns in the evolution of the Rab GTPase family in Archaeplastida. Acta Soc Bot Pol. 2014;83(4):303315. http://dx.doi.org/10.5586/asbp.2014.052

101. Martin W, Rujan T, Richly E, Hansen A, Cornelsen S, Lins T, et al Evolutionary analysis of Arabidopsis, cyanobacterial, and chloroplast genomes reveals plastid phylogeny and thousands of cyanobacterial genes in the nucleus. Proc Natl Acad Sci USA. 2002;99(19):1224612251. http://dx.doi.org/10.1073/pnas.182432999

102. Reyes-Prieto A, Hackett JD, Soares MB, Bonaldo MF, Bhattacharya D. Cyanobacterial contribution to algal nuclear genomes is primarily limited to plastid functions. Curr Biol. 2006;16(23):2320-2325. http:// dx.doi.org/10.1016/j.cub.2006.09.063

103. Moustafa A, Bhattacharya D. PhyloSort: a user-friendly phylogenetic sorting tool and its application to estimating the cyanobacterial contribution to the nuclear genome of Chlamydomonas. BMC Evol Biol. 2008;8:6. http://dx.doi.org/10.1186/1471-2148-8-6

104. Deusch O, Landan G, Roettger M, Gruenheit N, Kowallik KV, Allen JF, et al. Genes of cyanobacterial origin in plant nuclear genomes point to a heterocyst-forming plastid ancestor. Mol Biol Evol. 2008;25(4):748761. http://dx.doi.org/10.1093/molbev/msn022

105. Sato N, Ishikawa M, Fujiwara M, Sonoike K. Mass identification of chloroplast proteins of endosymbiont origin by phylogenetic profiling based on organism-optimized homologous protein groups. Genome Inform. 2005;16(2):56-68.

106. Lang BF, Nedelcu AM. Plastid genomes of algae. In Bock R, Knoop V, editors. Genomics of chloroplasts and mitochondria. Advances in photosynthesis and respiration series. Volume 35. Dordrecht: Springer Netherlands; 2012. p. 59-87. http://dx.doi. org/10.1007/978-94-007-2920-9_3

107. DePriest MS, Bhattacharya D, López-Bautista JM. The plastid genome of the red macroalga Grateloupia taiwanensis (Halymeniaceae) PLoS One. 2013;8(7):e68246. http://dx.doi.org/10.1371/journal. pone.0068246

108. Wang L, Mao Y, Kong F, Li G, Ma F, Zhang B, et al. Complete sequence and analysis of plastid genomes of two economically important red algae: Pyropia haitanensis and Pyropia yezoensis. PLoS One. 2013;8(5):e65902. http://dx.doi.org/10.1371/journal.pone.0065902

109. Tajima N, Sato S, Maruyama F, Kurokawa K, Ohta H, Tabata S, et al. Analysis of the complete plastid genome of the unicellular red alga Porphyridium purpureum. J Plant Res. 2014;127(3):389-397. http:// dx.doi.org/10.1007/s10265-014-0627-1

110. Grossman AR, Talbot L, Egelhoff T. Biosynthesis of phycobilisome polypeptides of Porphyridium aerugineum and Cyanophora paradoxa. In: Year book Carnegie Institution of Washington. Washington, DC: Carnegie Institution of Washington; 1983. p. 112-116.

111. Steiner JM, Pompe JA, Löffelhardt W. Characterization of $a p c C$, the nuclear gene for the phycobilisome core linker polypeptide $\mathrm{L}(\mathrm{c})(7.8)$ from the glaucocystophyte alga Cyanophora paradoxa. Import of the precursor into isolated cyanelles and integration of the mature protein into intact phycobilisomes. Curr Genet. 2003;44(3):132-137. http:// dx.doi.org/10.1007/s00294-003-0433-0

112. Tomitani A, Okada K, Miyashita H, Matthijs HC, Ohno T, Tanaka A. Chlorophyll $b$ and phycobilins in the common ancestor of cyanobacteria and chloroplasts. Nature. 1999;400(6740):159-162. http:// dx.doi.org/10.1038/22101

113. David L, Marx A, Adir N. High-resolution crystal structures of trimeric and rod phycocyanin. J Mol Biol. 2011;405(1):201-213. http://dx.doi. org/10.1016/j.jmb.2010.10.036

114. Engelken J, Brinkmann H, Adamska I. Taxonomic distribution and origins of the extended LHC (light-harvesting complex) antenna protein superfamily. BMC Evol Biol. 2010;10:233. http://dx.doi. org/10.1186/1471-2148-10-233

115. Umate P. Genome-wide analysis of the family of light-harvesting chlorophyll $a / b$-binding proteins in Arabidopsis and rice. Plant Signal Behav. 2010;5(12):1537-1542. http://dx.doi.org/10.4161/ psb.5.12.13410

116. Montané MH, Kloppstech K. The family of light-harvesting-related proteins (LHCs, ELIPs, HLIPs): was the harvesting of light their primary function? Gene. 2000;258(1-2):1-8. http://dx.doi.org/10.1016/ S0378-1119(00)00413-3

117. Koziol AG, Borza T, Ishida KI, Keeling P, Lee RW, Durnford DG. Tracing the evolution of the light-harvesting antennae in chlorophyll $a / b$-containing organisms. Plant Physiol. 2007;143(4):1802-1816. http://dx.doi.org/10.1104/pp.106.092536

118. van Heijenoort J. Formation of the glycan chains in the synthesis of bacterial peptidoglycan. Glycobiology. 2001;11(3):25R-36R. http:// dx.doi.org/10.1093/glycob/11.3.25R

119. Vollmer W, Blanot D, de Pedro MA. Peptidoglycan structure and architecture. FEMS Microbiol. Rev. 2008;32(2):149-167. http://dx.doi. org/10.1111/j.1574-6976.2007.00094.x

120. Pfanzagl B, Zenker A, Pittenauer E, Allmaier G, Martinez-Torrecuadrada J, Schmid ER, et al. Primary structure of cyanelle peptidoglycan of Cyanophora paradoxa: a prokaryotic cell wall as part of an organelle envelope. J Bacteriol. 1996;178(2):332-339.

121. Pfanzagl B, Allmaier G, Schmid ER, de Pedro MA, Löffelhardt W. $\mathrm{N}$-acetylputrescine as a characteristic constituent of cyanelle peptidoglycan in glaucocystophyte algae. J Bacteriol. 1996;178(23):6994-6997.

122. Schwartzbach SD, Osafune T, Löffelhardt W. Protein import into cyanelles and complex chloroplasts. Plant Mol Biol. 1998;38(1-2):247263. http://dx.doi.org/10.1023/A:1006029919283

123. Plaimauer B, Pfanzagl B, Berenguer J, de Pedro MA, Löffelhardt W. Subcellular distribution of enzymes involved in the biosynthesis of cyanelle murein in the protist Cyanophora paradoxa. FEBS Lett. 1991;284(2):169-172. http://dx.doi. org/10.1016/0014-5793(91)80677-U

124. Iino M, Hashimoto $\mathrm{H}$. Intermediate features of cyanelle division of Cyanophora paradoxa (Glaucocystophyta) between cyanobacterial and plastid division. J Phycol. 2003;39(3):561-569. http://dx.doi. org/10.1046/j.1529-8817.2003.02132.x

125. Berenguer J, Rojo F, de Pedro MA, Pfanzagl B, Löffelhardt W. Penicillin-binding proteins in the cyanelles of Cyanophora paradoxa, a eukaryotic photoautotroph sensitive to $\beta$-lactam antibiotics. FEBS Lett. 1987;224(2):401-405. http://dx.doi.org/10.1016/0014-5793(87)80492-1

126. Kies L. The effect of penicillin on the morphology and ultrastructure of Cyanophora, Gloeochaete and Glaucocystis (Glaucocystophyceae) and their cyanelles. Endocytobiosis Cell Res. 1988;5:361-372.

127. Sato M, Nishikawa T, Kajitani H, Kawano S. Conserved relationship between FtsZ and peptidoglycan in the cyanelles of Cyanophora paradoxa similar to that in bacterial cell division. Planta. 2007;227(1):177-187. http://dx.doi.org/10.1007/s00425-007-0605-0

128. Miyagishima SY, Takahara M, Mori T, Kuroiwa H, Higashiyama T, Kuroiwa T. Plastid division is driven by a complex mechanism that involves differential transition of the bacterial and eukaryotic division rings. Plant Cell. 2001;13(10):2257-68. http://dx.doi.org/10.1105/ tpc. 010185

129. Miyagishima S, Kabeya Y, Sugita C, Sugita M, Fujiwara T. DipM is 
required for peptidoglycan hydrolysis during chloroplast division. BMC Plant Biol. 2014;14:57. http://dx.doi.org/10.1186/1471-2229-14-57

130. Kies L. Untersuchungen zur Feinstruktur und taxonomischen Einordnung von Gloeochaete wittrockiana, einer apoplastidalen capsalen Alge mit blaugrünen Endosymbionten (Cyanellen). Protoplasma. 1976;87(4):419-446. http://dx.doi.org/10.1007/BF01624010

131. Mangeney E, Gibbs SP. Immunocytochemical localization of ribulose-1,5-bisphosphate carboxylase/oxygenase in the cyanelles of Cyanophora paradoxa and Glaucocystis nostochinearum. Eur J Cell Biol. 1987;43(1):65-70. http://dx.doi.org/10.1104/pp.84.4.1028

132. Burey SC, Fathi-Nejad S, Poroyko V, Steiner JM, Löffelhardt W, Bohnert HJ. The central body of the cyanelles of Cyanophora paradoxa: a eukaryotic carboxysome? Can J Bot. 2005;83(7):758-764. http:// dx.doi.org/10.1139/b05-060

133. Giordano M, Beardall J, Raven JA. $\mathrm{CO}_{2}$ concentrating mechanisms in algae: mechanisms, environmental modulation, and evolution. Annu Rev Plant Biol. 2005;56:99-131. http://dx.doi.org/10.1146/annurev. arplant.56.032604.144052

134. Burey SC, Poroyko V, Ergen ZN, Fathi-Nejad S, Schüller $\mathrm{C}$, Ohnishi $\mathrm{N}$, et al. Acclimation to low $\left[\mathrm{CO}_{2}\right]$ by an inorganic carbon-concentrating mechanism in Cyanophora paradoxa. Plant Cell Environ. 2007;30(11):1422-1435. http://dx.doi. org/10.1111/j.1365-3040.2007.01715.x

135. Raven JA. Carboxysomes and peptidoglycan walls of cyanelles: possible physiological functions. Eur J Phycol. 2003;38(1):47-53. http:// dx.doi.org/10.1080/0967026031000096245

136. Börner G V, Mörl M, Janke A, Pääbo S. RNA editing changes the identity of a mitochondrial tRNA in marsupials. EMBO J. 1996;15(21):5949-5957.

137. Valach M, Burger G, Gray MW, Lang BF. Widespread occurrence of organelle genome-encoded 5S rRNAs including permuted molecules. Nucleic Acids Res. 2014;42(22):13764-13777. http://dx.doi. org/10.1093/nar/gku1266

138. Verbruggen H, Maggs CA, Saunders GW, Le Gall L, Yoon HS, de Clerck O. Data mining approach identifies research priorities and data requirements for resolving the red algal tree of life. BMC Evol Biol. 2010;10:16. http://dx.doi.org/10.1186/1471-2148-10-16

139. Leliaert F, Smith DR, Moreau H, Herron MD, Verbruggen H, Delwiche $\mathrm{CF}$, et al. Phylogeny and molecular evolution of the green algae. Crit Rev Plant Sci 2012;31(1):1-46. http://dx.doi.org/10.1080/07352689 .2011 .615705 